\title{
Structural and Chemical Biology of Presenilin Complexes
}

\author{
Douglas S. Johnson, ${ }^{1}$ Yue-Ming Li, ${ }^{2}$ Martin Pettersson, ${ }^{1}$ and Peter H. St George-Hyslop ${ }^{3,4}$ \\ ${ }^{1}$ Pfizer Worldwide Research and Development, Cambridge, Massachusetts 02139 \\ ${ }^{2}$ Chemical Biology Program, Memorial Sloan Kettering Cancer Center, New York, New York 10065 \\ ${ }^{3}$ Cambridge Institute for Medical Research, Wellcome Trust MRC Building, Addenbrookes Hospital, Cambridge \\ CB2 OXY, United Kingdom \\ ${ }^{4}$ Tanz Centre for Research in Neurodegenerative Diseases and Departments of Medicine, Laboratory Medicine \\ and Pathobiology, and Medical Biophysics, University of Toronto, Toronto, Ontario M5T 2S8, Canada \\ Correspondence: phs22@cam.ac.uk
}

\begin{abstract}
The presenilin proteins are the catalytic subunits of a tetrameric complex containing presenilin 1 or 2, anterior pharynx defective 1 (APH1), nicastrin, and PEN-2. Other components such as TMP21 may exist in a subset of specialized complexes. The presenilin complex is the founding member of a unique class of aspartyl proteases that catalyze the $\gamma, \varepsilon, \zeta$ site cleavage of the transmembrane domains of Type I membrane proteins including amyloid precursor protein (APP) and Notch. Here, we detail the structural and chemical biology of this unusual enzyme. Taken together, these studies suggest that the complex exists in several conformations, and subtle long-range (allosteric) shifts in the conformation of the complex underpin substrate access to the catalytic site and the mechanism of action for allosteric inhibitors and modulators. Understanding the mechanics of these shifts will facilitate the design of $\gamma$-secretase modulator (GSM) compounds that modulate the relative efficiency of $\gamma, \varepsilon, \zeta$ site cleavage and/or substrate specificity.
\end{abstract}

Thersing he presenilin (PS) genes were first identified during searches for genes responsible for early onset, autosomal dominant forms of familial Alzheimer's disease (FAD) (Rogaev et al. 1995; Sherrington et al. 1995). The genes are highly conserved in evolution, but in vertebrates, there are two highly similar homologous presenilin genes: PSEN1 (on chromosome 14 in humans, encoding PS1) and PSEN2 (on chromosome 1, encoding PS2). Both PS1 and PS2 are $\sim 50-\mathrm{kDa}$ polytopic transmembrane (TM) proteins that interact with nicastrin, PEN-2, and anterior pharynx defective 1 (APH1) to form a 1:1:1:1 heterotetrameric complex (Fig. 1) (Li et al. 2014). Presenilin complexes lacking any one of their subunits are destabilized and degraded (Takasugi et al. 2003). However, a subset of complexes may contain additional TM proteins such as TMP21, which may have a regulatory function (Chen et al. 2006). The biologically active complex performs regulated cleavage through the transmembrane domains

Editor: Stanley B. Prusiner

Additional Perspectives on Prion Diseases available at www.perspectivesinmedicine.org

Copyright (C) 2017 Cold Spring Harbor Laboratory Press; all rights reserved; doi: 10.1101/cshperspect.a024067

Cite this article as Cold Spring Harb Perspect Med 2017;7:a024067 
D.S. Johnson et al.

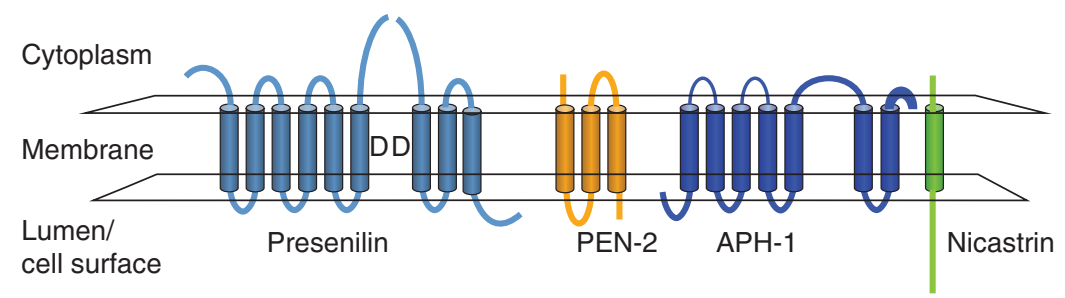

Figure 1. A diagrammatic representation of the presenilin-complex subunit component proteins including presenilin, PEN-2, anterior pharynx defective 1 (APH1), and nicastrin. The orientations of the membrane proteins relative to the cytoplasmic and lumenal faces of the membrane are depicted. Presenilin has nine predicted transmembrane (TM) domains, PEN-2 has two partial TM domains and a final fully spanning TM domain, APH1 has seven, and nicastrin has one TM domain.

of selected Type I TM proteins (Fig. 2) (De Strooper et al. 1999; Nishimura et al. 1999; Wolfe et al. 1999b; Francis et al. 2002; Yu et al. 2000; Chen et al. 2006).

\section{TOPOLOGY AND STRUCTURE OF PRESENILIN-COMPLEX COMPONENTS}

\section{Presenilin}

Presenilin PS1 (and PS2) are the catalytic subunits of the heterotetrameric presenilin 1 (or presenilin 2) complexes (Wolfe et al. 1999b; Li et al. 2000a; Chen et al. 2006; Ahn et al. 2010) and are the founding members of the GXGD family of intramembranous aspartyl proteases. Other members of this protease family include signal peptide peptidases (SPP) and a variety of archaeal homologs (Weihofen et al. 2002; Martoglio and Golde 2003; Friedmann et al. 2004; Fluhrer et al. 2009; Lu et al. 2012a). These proteins will not be discussed in detail here except to note that they are monomeric or dimeric, and they have an opposite topology to the membrane relative to the presenilin proteins.

The presenilin proteins have nine helical TM domains arranged with the hydrophilic, flexible $\mathrm{N}$ terminus in the cytosol and the $\mathrm{C}$ terminus protruding into the lumen or extracellular space (Doan et al. 1996; Laudon et al. 2005; Wolfe 2013). TM6 and TM7 each contain one of two catalytic aspartyl residues (Wolfe et al. 1999b). During the assembly and maturation of presenilin complexes, the PS1 or PS2 subunits undergo endoproteolytic cleavage into $\mathrm{N}$ - and C-terminal fragments, which then remain stably associated with each other (Thinakaran et al. 1996; Steiner et al. 2008; De Strooper and Annaert 2010). For PS1, the cleavage occurs near residue Met298 (encoded by exon 9) within the cytoplasmic peptide loop connecting TM6 and TM7 (Podlisny et al. 1997). Missense mutations in the presenilins alter the relative abundance of amyloid- $\beta$ (A $\beta$ ) peptide species produced during presenilin-complexmediated cleavage of APP-C100 following BACE cleavage of APP (Scheuner et al. 1996; Citron et al. 1997; Chávez-Gutiérrez et al. 2012).

PS1 and PS2 have highly similar amino acid sequences and topologies. One crucial difference appears to be a "[DIE] xxxL/I/M" motif in PS2 that interacts in a phosphorylationdependent manner with AP-1 complexes and targets PS2 to the late endosome/lysosome complex. The absence of this sequence motif in PS1 allows for the wider subcellular location of PS1 in cell membranes (Sannerud et al. 2016).

During the two decades since the presenilin genes were first cloned, several attempts have been made to deduce the three-dimensional structure of the presenilin proteins using multiple methods including cross-linking (Watanabe et al. 2010) and solution nuclear magnetic resonance (NMR) of subfragments (PDB code 2KR6) (Sobhanifar et al. 2010). Additionally, a crystal structure has been generated for a distant and highly atypical presenilin homolog isolated from the archaeon Methanoculleus marisnigri JR1 (MCMJR1 or MmPSH) (PDB code 4HYG) (Li et al. 2013). MmPSH has a PS-like topology 
Presenilin Structure and Medicinal Chemistry

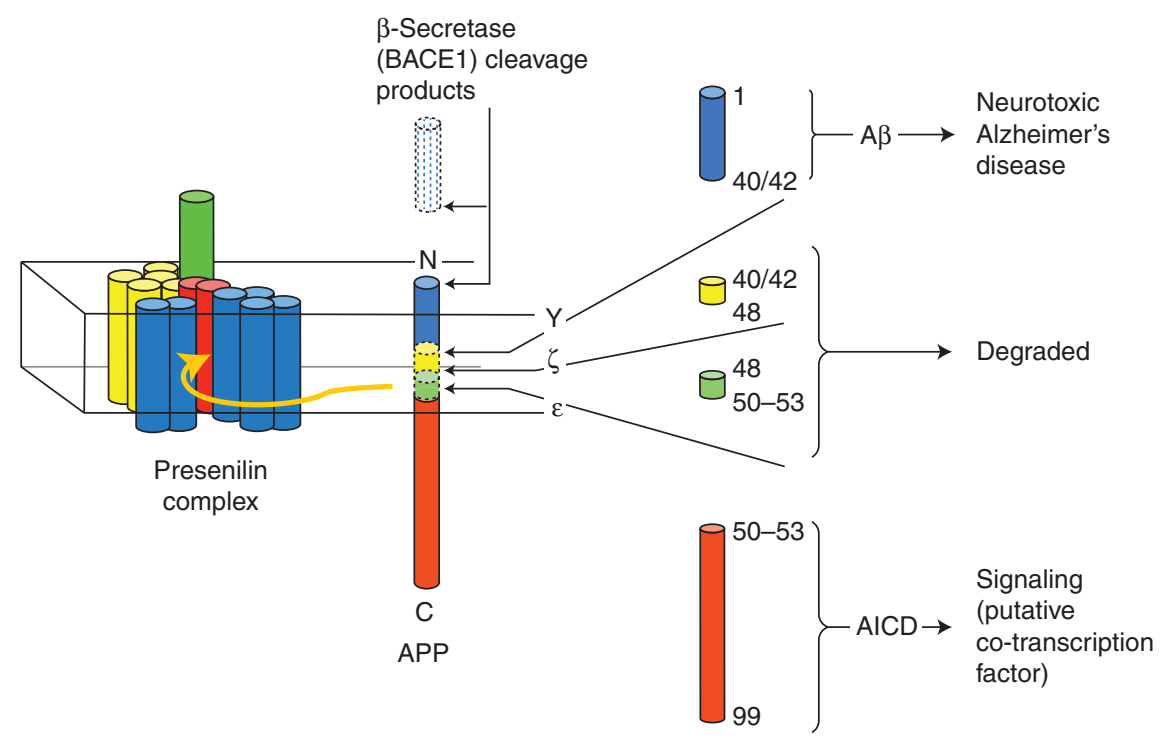

Figure 2. A diagrammatic representation of the intramembranous cleavage sites within the transmembrane (TM) domain of substrate proteins is shown using the APP-C100 substrate released from full-length APP by prior $\beta$-secretase cleavage as the canonical substrate. The predominant and minor series of cleavages are depicted. The N-terminal fragment forms the amyloid- $\beta$ (A $\beta$ ) peptide associated with neurotoxicity in Alzheimer's disease $(\mathrm{AD})$. The $\mathrm{C}$-terminal fragment is a putative signaling molecule that can be translocated to the nucleus. The two smaller internal fragments are rapidly degraded.

but has only weak presenilin-like $\gamma$-secretase activity and, paradoxically, significant signalpeptide peptidase activity (R Dodd, S Qamar, and C Bohm, unpubl.). The crystal structure of MmPSH must be interpreted with caution in light of three caveats. First, it was generated from a modified, catalytically inactive construct. Second, the two catalytic aspartate residues are not in close enough proximity for catalysis to occur, suggesting that the TM domains have moved during crystallization. Third, there are several other features to this structure that likely represent crystallization artifacts. For instance, the TM6 helices are displaced and insert among the TM helices of other nearby tetramers within the crystal arrays-an occurrence that is unlikely to be physiological.

\section{Nicastrin}

Nicastrin is a Type I integral membrane protein that consists of a large $\mathrm{N}$-terminal extracellular glycosylated ectodomain that contains a con- served DYIGS motif, a transmembrane helical domain, and a very short cytoplasmic C terminus (Yu et al. 2000). Nicastrin binds to APH1 and forms an initial scaffolding molecule that may regulate intracellular trafficking of the nascent presenilin complex during its assembly (Shirotani et al. 2003; Zhang et al. 2005; Spasic et al. 2007). Within the assembled presenilin complex, nicastrin binds to the $\mathrm{C}$ terminus of PS1 (Bergman et al. 2004).

In addition to the role of nicastrin in regulating presenilin-complex assembly, the ectodomain of nicastrin, which contains a conserved DYIGS motif, may be involved in substrate selection and acquisition by detecting the lengths of extracellular N-terminal protrusions of substrate proteins and by excluding Type I membrane proteins that have not undergone a prior $\alpha$ - or $\beta$-secretase-like sheddase cleavage to release most of the N-terminal domain (Shah et al. 2005). However, nicastrin is not essential for $\gamma$-secretase activity (Ahn et al. 2010; Zhao et al. 2010). The ectodomain of nicastrin has 
D.S. Johnson et al.

a predicted aminopeptidase/transferrin receptor-like structure similar to that of the human transferrin receptor (PDB code 1CX8) and the glutamate carboxyl peptidase PSMA (PDB code 2XEF) (Fagan et al. 2001). This structural homology, which supports a role in substrate acquisition but not cleavage, was recently confirmed in a cryo-electron microscopy (cryo-EM) study (Lu et al. 2014) (PDB code 4UPC) and by crystallography of a distant Dictyostelium homolog (PDB code 4R12) (Xie et al. 2014).

\section{PEN-2 and APH1}

Relatively less is known about the structural biology and function of PEN-2 and APH1. Both were identified during genetic screens for enhancers and suppressors of Notch signaling (Francis et al. 2002).

PEN-2 is a 101-residue (12-kDa) membrane protein with three predicted transmembrane domains - the first two of which are re-entrant and only partially cross the bilayer and a third that is a complete TM helix (Lu et al. 2014; Bai et al. 2015a,b; Zhang et al. 2015). The $\mathrm{N}$ terminus is cytosolic, whereas the $\mathrm{C}$ terminus is luminal. PEN-2 binds to TM4 of PS1 (Kim and Sisodia 2005; Watanabe et al. 2005) and may stabilize the presenilin complex during its final assembly and maturation (Prokop et al. 2004; Holmes et al. 2014).

APH1 (Francis et al. 2002) is encoded in humans by two paralogous genes (APH1A on chromosome 1 and APH1B on chromosome 15), which produce two highly similar gene products of about 195-265 residues. A further duplication of the APH1B gene in mice gave rise to a third APH1 family gene, APH1C. Because any given presenilin complex has only a single APH1 protein, the existence of APH1A, $\mathrm{APH} 1 \mathrm{~B}$, and $\mathrm{APH} 1 \mathrm{C}$ allows two different types of each PS1 or PS2 complex in humans and three different types in mice. These different isoforms may have subtly different activities (Serneels et al. 2005, 2009). APH1 has a sevenTM topology with its $\mathrm{N}$ terminus in the lumen and its $\mathrm{C}$ terminus in the cytoplasm (Fortna et al. 2004). All human and mouse APH1 paral- ogs contain a conserved GXXXG motif that may be involved in interactions with other subunits of the presenilin complex (Lee et al. 2004). As noted above, the APH1:nicastrin complex likely forms an initial scaffold onto which PS1/PS2 and PEN-2 are subsequently added (Lee et al. 2002; Yang et al. 2002; Gu et al. 2003, 2004; Spasic et al. 2007; Pardossi-Piquard et al. 2009; Mao et al. 2012), with the PS1 or PS2 $\mathrm{C}$ terminus abutting APH1 (Bergman et al. 2004).

\section{Structure of the Presenilin Complex as a Whole Entity}

Recently, despite the small size and lack of symmetry, great strides have been made in understanding the three-dimensional structure of the presenilin complexes through application of EM and electron density mapping methods. The initial EM reconstruction studies before 2014 generated a variety of three-dimensional models differing in shape and volume (Lazarov et al. 2006; Ogura et al. 2006; Osenkowski et al. 2009; Renzi et al. 2011). None of these were validated using independent biophysical methods, and they were also not consistent with each other. However, as the analytical and statistical methods improved, several more recent and accurate models were published.

In the first of these models, negative-stain single-particle three-dimensional EM data were combined with several complementary crossvalidating biochemical, pharmacological, and biophysical methods, including size exclusion chromatography with multiangle light scattering (SEC-MALS) and Förster resonance energy transfer fluorescence lifetime imaging (FRETFLIM) (Li et al. 2014). The resulting 17- $\AA$ model revealed that presenilin complexes have a bi-lobed shape, with a larger base $(93 \times 93 \times$ $60 \AA)$ and a smaller head $(65 \times 60 \times 55 \AA)$ (Fig. 3A). The ectodomain of nicastrin is located in the head domain. The base of the bi-lobed complex contains the TM domains of the PS1/ PS2, PEN-2, nicastrin, and APH1 subunits (Fig. 3). Crucially, the base domain has a lateral cleft that communicates with the central cavity and that could potentially provide a route for sub- 
Presenilin Structure and Medicinal Chemistry
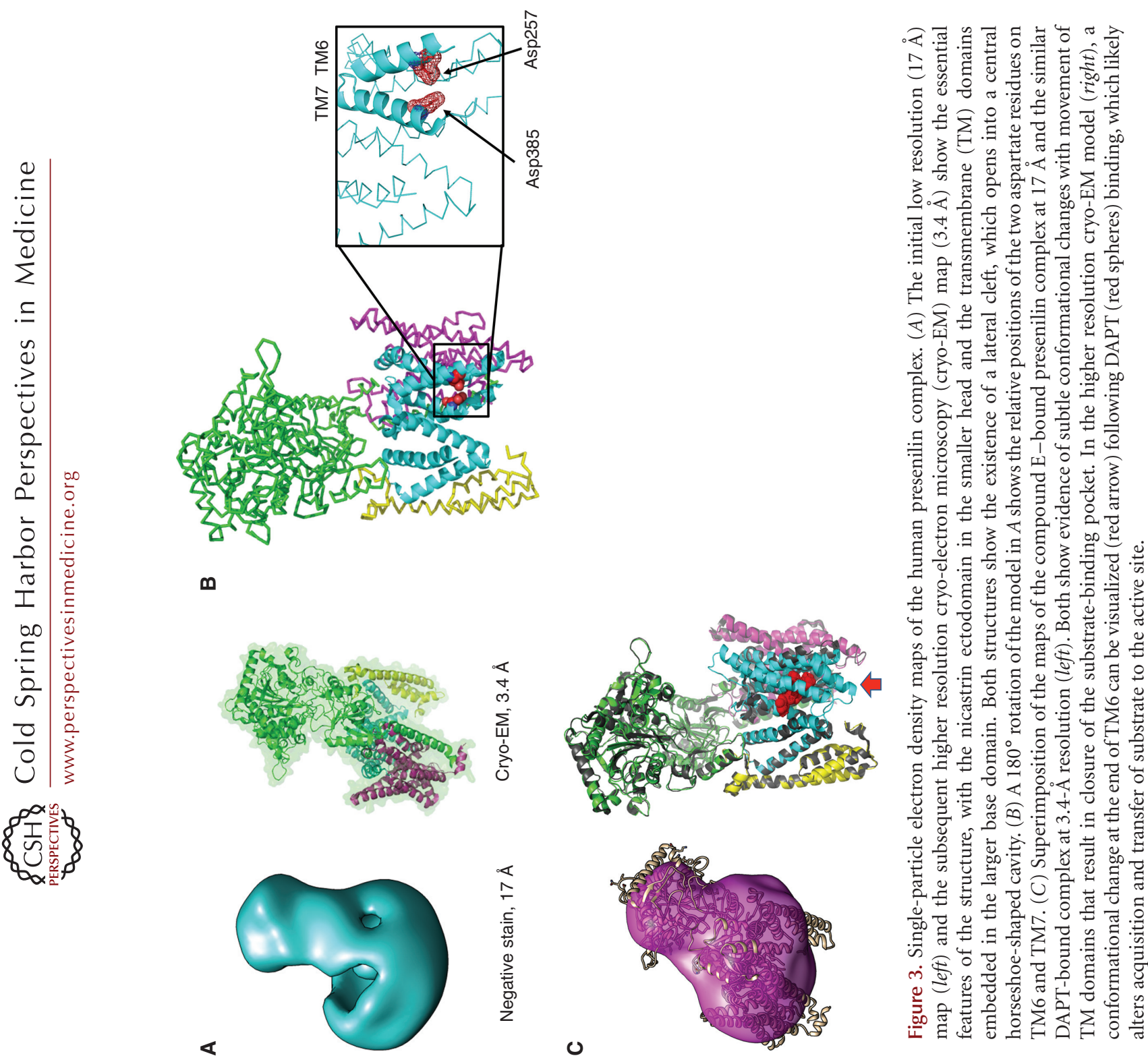
D.S. Johnson et al.

strate access to the catalytic PS1/PS2 subunit in the center of that horseshoe-shaped cavity.

More recently, the use of new detectors and image-processing methods has enabled further refinements of this model by increasing the image resolution to $4.5 \AA$ (EMD-2677 and -3061, PDB code 4UPC and 5A63) (Lu et al. 2014; Bai et al. 2015b). This higher-resolution model confirmed the bi-lobed shape of human presenilin complexes as their native state (Fig. 3). Interestingly, several of the recent EM structural studies have reported that within any isolate of pure PS1 complexes, the complexes exist in multiple different conformations (Bai et al. 2015b; Elad et al. 2015). This agrees well with previous pharmacological studies, which suggest that at any given time only a small proportion of complexes are catalytically active (Beher et al. 2003; Lai et al. 2003).

\section{Functional Anatomy of the Presenilin Complex}

The increasing resolution of three-dimensional EM models of the presenilin complex has ushered in a new era to investigate how certain inhibitor drugs work. As described in greater detail below, numerous compound series have been identified through a variety of chemical screening strategies as inhibitors or modulators of the secretase function of the presenilin complex. Only a minority of these compounds actually work at the catalytic site. Many compounds have complicated mechanisms of action that likely involve binding at a site remote from the catalytic pocket, but then allosterically modifying the conformation of the complex. Some of these modifications alter substrate binding and access to the catalytic pocket. Others alter substrate preference and/or the efficiency of specific cleavage events.

The chemistry of these compounds is described in detail in the following sections. The structural effect of these compounds is now the topic of intense investigation. Two non-transition-state peptidomimetic $\gamma$-secretase inhibitors - namely, DAPT and compound E [(S,S)-2-[2-(3,5-difluorophenyl)-acetylamino]$\mathrm{N}$-(1-methyl-2-oxo-5-phenyl-2,3-dihydro-1H- benzo[e] [1,4] diazepin-3-yl)-propionamide, molecular mass $=490.5 \mathrm{Da}]$ - have already been investigated using these methods (Li et al. 2014; Bai et al. 2015a). Compound E blocks substrate binding to the initial substrate-docking site ( $\mathrm{Li}$ et al. 2014). Moreover, compound E binding can stabilize the PS1 complex and prevent its detergent-induced dissociation (Li et al. 2014), suggesting that inhibitor binding causes a significant conformational change that brings the complex components closer together. Intriguingly, there is a reciprocal allosteric effect in which substrate binding to the initial substrate docking site increases subsequent to compound E binding (Li et al. 2014). The existence of these inhibitor-induced conformational shifts has been robustly validated by two different types of experiments. First, in vitro intramolecular FRET-FLIM methods demonstrated a significant change in FRETFLIM between tags placed on the PS1-NTF and PS1-CTF, indicating that the subcomponents of the complex had been brought closer together by compound $\mathrm{E}$ binding ( $\mathrm{Li}$ et al. 2014). Second, the single-particle three-dimensional EM structure model for compound Ebound PS1 complexes was highly similar to the native complexes, with a bi-lobed overall shape. However, there were several critical differences, including (1) rotation of the nicastrin-containing head domain, and (2) compaction of the membrane-embedded base domain with closure of the lateral cleft (Fig. 3C) (Li et al. 2014). Similar changes at higher resolution have now been documented for DAPT, a similar peptidomimetic inhibitor (Fig. 3C) (Bai et al. 2015a). DAPT causes several conformational shifts including a shift in the presence of a tripeptide motif at the end of TM6, which may facilitate selection, acquisition, and transfer of substrate TMs to the catalytic site ( $R$ Dodd, S Qamar, and C Bohm, unpubl.).

Taken together, these observations suggest that the presenilin complexes are structurally dynamic complexes, and shifts in their conformation induced by ligand/substrate or inhibitor/modulator binding are reflected by changes in function. Below, we describe some of these compounds, many of which will be explored for 
their effects on presenilin-complex conformation in the near future.

\section{CHEMICAL BIOLOGY OF THE PRESENILIN COMPLEX}

\section{$\gamma$-Secretase Inhibitors (GSIs)}

A variety of GSIs with distinct structures have been discovered (Josien 2002; D’Onofrio et al. 2012). Here, we focus on three types of GSIs: exosite-targeted GSIs, active site-directed GSI probes, and GSIs in clinical trials for treatment of $\mathrm{AD}$ and cancer.

\section{Exosite-Targeted GSIs}

The use of docking sites for substrate recognition represents a unique biological mechanism to achieve specificity in complex systems containing multiple component proteins. These docking sites, which are also referred to as exosites, are defined as specialized substrate binding sites located in separate domains outside the active site of the enzyme. They have been discovered in thrombin and matrix metalloproteinase and function to modulate and broaden substrate specificity (Overall 2002; Krishnaswamy 2005). $\gamma$-Secretase is a macromolecular complex that contains multiple exosites that are capable of interacting with substrates. Initially, Tian et al. (2002) demonstrated that at least two sites exist in the $\gamma$-secretase complex: the docking site and the active site. Moreover, kinetic studies using the TM domain of the APP substrate suggest that the TM domain does not interact with the docking site, and either the extracellular or intracellular region of $\beta C T F$ binds to the docking site (Yin et al. 2007). It has been reported that the APP substrate interacts with $\gamma$-secretase at three other regions in addition to the active site. First, a docking site residing in the extracellular domain of nicastrin interacts with the N-terminal fragment of APP- $\beta$ CTF (Shah et al. 2005), although the precise binding region on APP- $\beta C T F$ has not been defined. Second, Kornilova et al. (2005) searched for substrate-binding sites by designing helical peptides that mimic the APP transmembrane domain. This study suggested that this interaction site was located on PS, adjacent to the active site. Third, a substrate inhibitory domain (ASID) of the APP substrate interacts with a site that consists of at least PS1NTF, PS1-CTF, and nicastrin (Tian et al. 2010). Although the exact binding sites have not yet been mapped, the existence of these exosites on $\gamma$-secretase is well documented in multiple studies (Tian et al. 2002, 2010; Kornilova et al. 2005; Yin et al. 2007). How these interaction regions coordinate to regulate $\gamma$-secretase activity and specificity is an exciting area of investigation. Accordingly, substrate-based peptidomimetic inhibitors and probes have been developed (Fig. 4A). Moreover, ASID-based inhibitors exhibit specificity for APP over Notch substrate (Tian et al. 2010). Because $\boldsymbol{\gamma}$-secretase cleaves multiple substrates, it is of interest to investigate whether unique regulatory sequences are present in other $\gamma$-secretase substrates and function in the modulation of their own processing by interacting with specific ASID sites within $\gamma$-secretase, as observed with APP.

\section{Active Site-Directed GSI Probes}

Since Shearman et al. (2000) reported L$685,458(\mathrm{~L}-458)$ as a potent $\gamma$-secretase inhibitor, molecular probes based on this molecule have been extensively developed ( $\mathrm{Li}$ et al. 2000b; Xu et al. 2002; Beher et al. 2003; Chun et al. 2004; Placanica et al. 2009; Yang et al. 2009; Teranishi et al. 2010; Crump et al. 2012a; Ballard et al. 2014; Gertsik et al. 2014) and have offered valuable tools for investigating $\gamma$-secretase (Fig. 4B-D). L458 and its derivatives contain a hydroxyethylene dipeptide transition-state isostere that only interacts with the active form of aspartyl proteases. These probes have successfully identified PS1 as the catalytic subunit of $\gamma$-secretase (Li et al. 2000b) and have shown that PS1 is associated with active $\gamma$-secretase in the plasma membrane to address the issue of "spatial paradox" (Tarassishin et al. 2004). Moreover, these probes interact with the PSNTF/PS-CTF heterodimer, the active form of $\gamma$-secretase, but not with PS full-length, suggesting that the PS full-length complex func- 
D.S. Johnson et al.

tions as a zymogen (Li et al. 2000b; Ahn et al. 2010). Importantly, these activity-based probes revealed that at least two types of PS complexes (the active and inactive) coexist in cells, and only a small fraction $(<14 \%)$ of the PS1 complex is catalytically active (Beher et al. 2003; Lai et al. 2003). Therefore, separation of the active PS $\gamma$-secretase form from its inactive form is necessary for elucidating the function of PS1engaged $\gamma$-secretase. Using these probes, some studies have shown that PS1 wild-type and FAD mutants differentially affect the equilibrium of the PS1- and PS2-containing active $\gamma$-secretase complexes, and the expression of Pen2 and PS1 mutants alter the stoichiometry of subunits within the $\gamma$-secretase complexes (Placanica et al. 2009). Consequently, these probes have been used for isolation of active $\gamma$-secretase complexes and identification of HIF $1 \alpha$ as a regulatory subunit of $\gamma$-secretase (Villa et al. 2014). An integrated approach with multiple photoprobes, referred to as photophore walking, has been developed for detection of conformational changes of the active site of $\gamma$-secretase by genetic mutations or small molecules (Shelton et al. 2009; Chau et al. 2012), offering a practical means for analyzing the active site of endogenous $\gamma$-secretase and insights into the mechanism of $\gamma$-secretase specificity. Photophore walking studies suggest that PS1 mutations alter the S2 subsite of the active site that allows for accommodation of larger P2 residues, leading to preference of the enzyme for $A \beta 42$ cleavage (Chau et al. 2012). In contrast, the binding of acid GSMs to PS1 allosterically changes the S1 subsite within the active site and ultimately leads to a selective lowering of $A \beta 42$ (Crump et al. 2011).

Other transition-state inhibitors were developed by Wolfe and colleagues (Fig. 4E) including APP substrate-based difluoro ketone compounds and hydroxyethyl urea peptidomimetics. These probes have successfully been used for characterization, identification, and isolation of $\gamma$-secretase, as well as for investigating the active site of $\gamma$-secretase and the mechanism of reaction (Wolfe et al. 1999a,b; Esler et al. 2000, 2002, 2004; Kimberly et al. 2003; Kornilova et al. 2003, 2005) in which $\gamma$-secretase substrates dock to the initial binding site or exosite and then reach the active site for hydrolysis (Kornilova et al. 2005).

\section{Clinical GSIs for AD}

Semagacestat (Fig. 4F) was the first GSI to enter phase III clinical trials. Despite encouraging results obtained from earlier clinical investigations (Siemers et al. 2007), the phase III trial failed because of the unexpected observation that semagacestat caused worsening of memory in patients (Doody et al. 2013). There was also an increased risk of skin cancer, which probably stemmed from Notch inhibition (Xia et al.

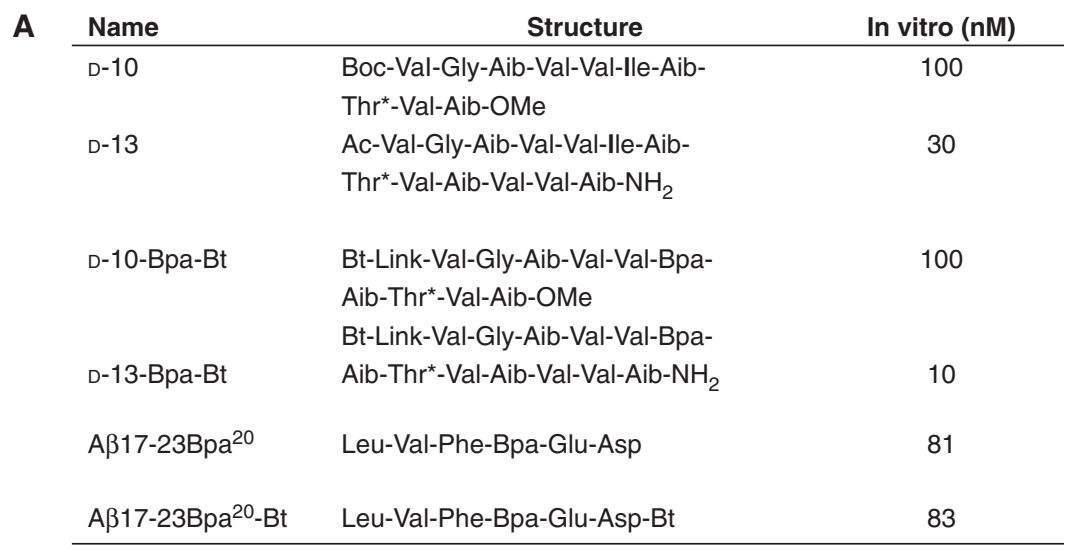

Figure 4. Structure of $\gamma$-secretase inhibitor compounds. (A) Substrate-based peptidomimetic inhibitors and probes. (Continued on following pages.) 
Presenilin Structure and Medicinal Chemistry
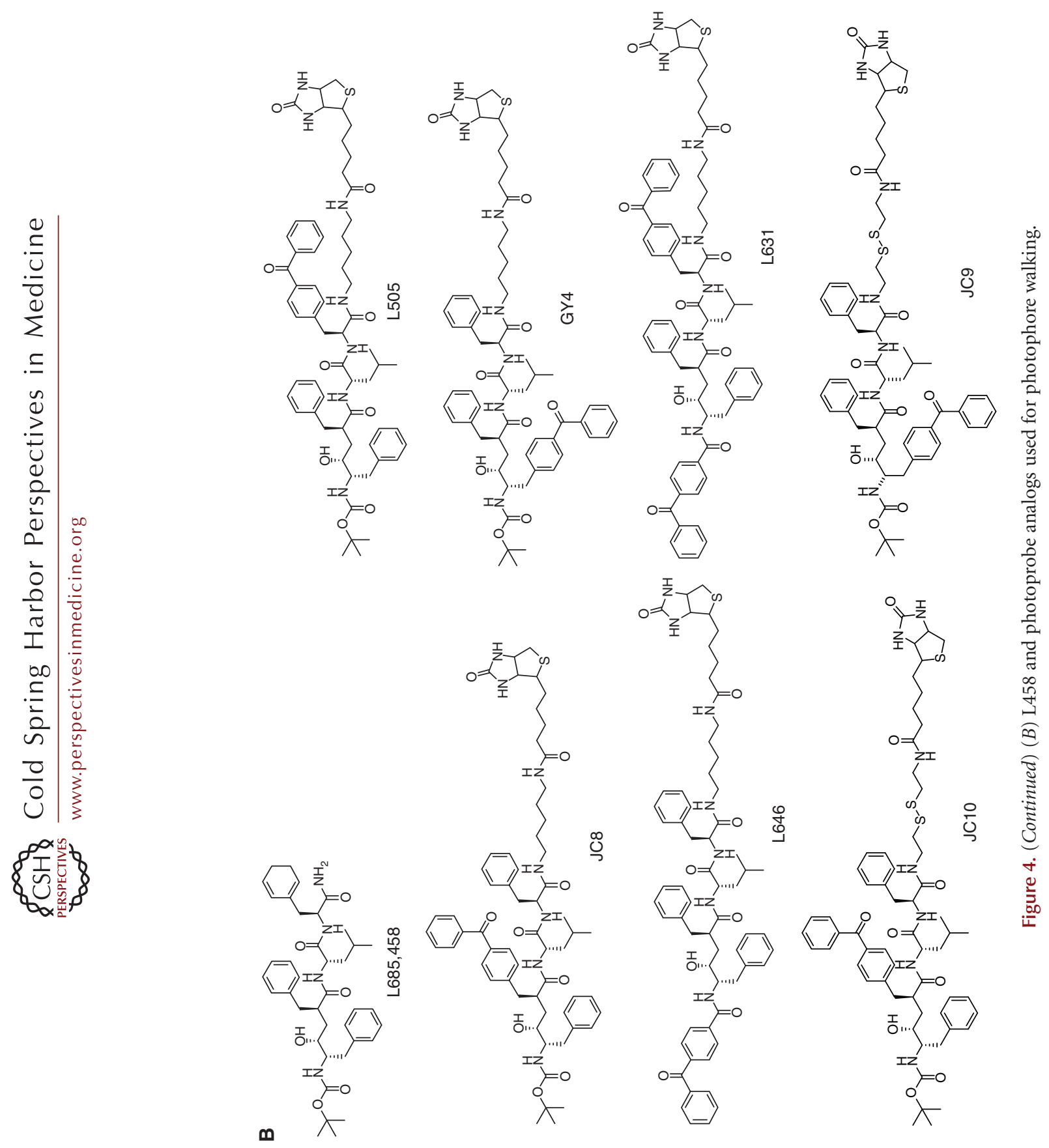
D.S. Johnson et al.
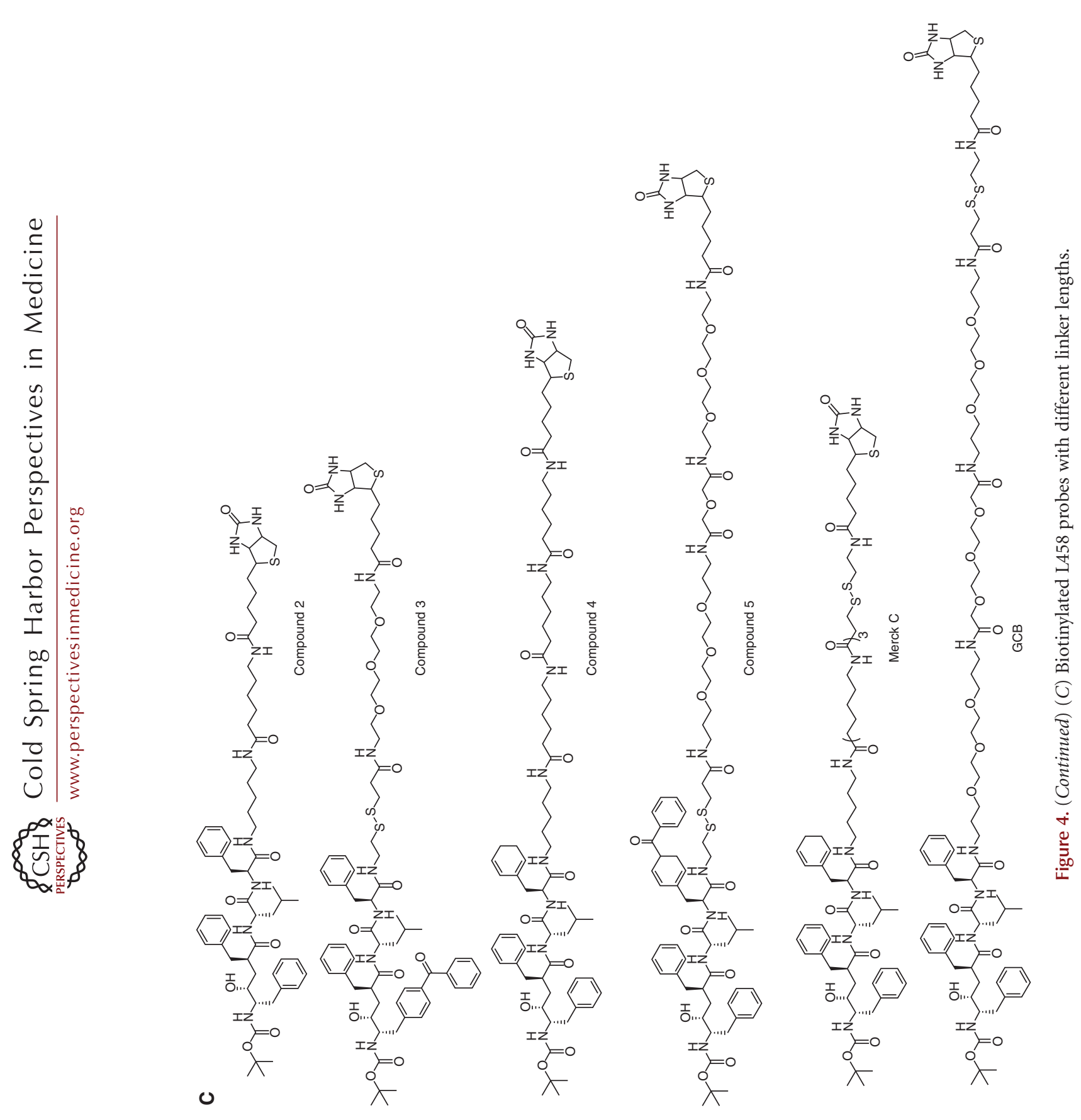
Presenilin Structure and Medicinal Chemistry

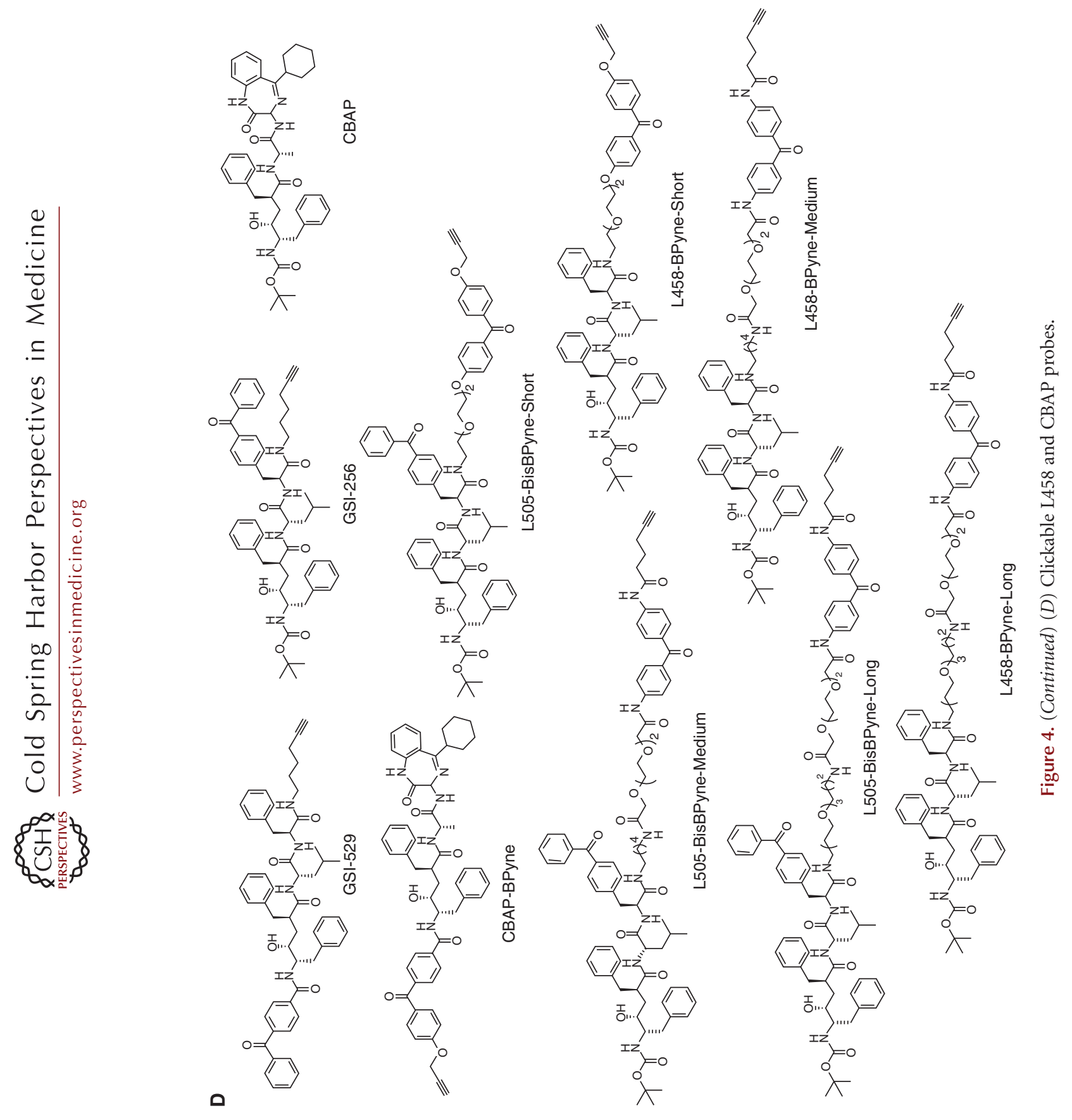


D.S. Johnson et al.
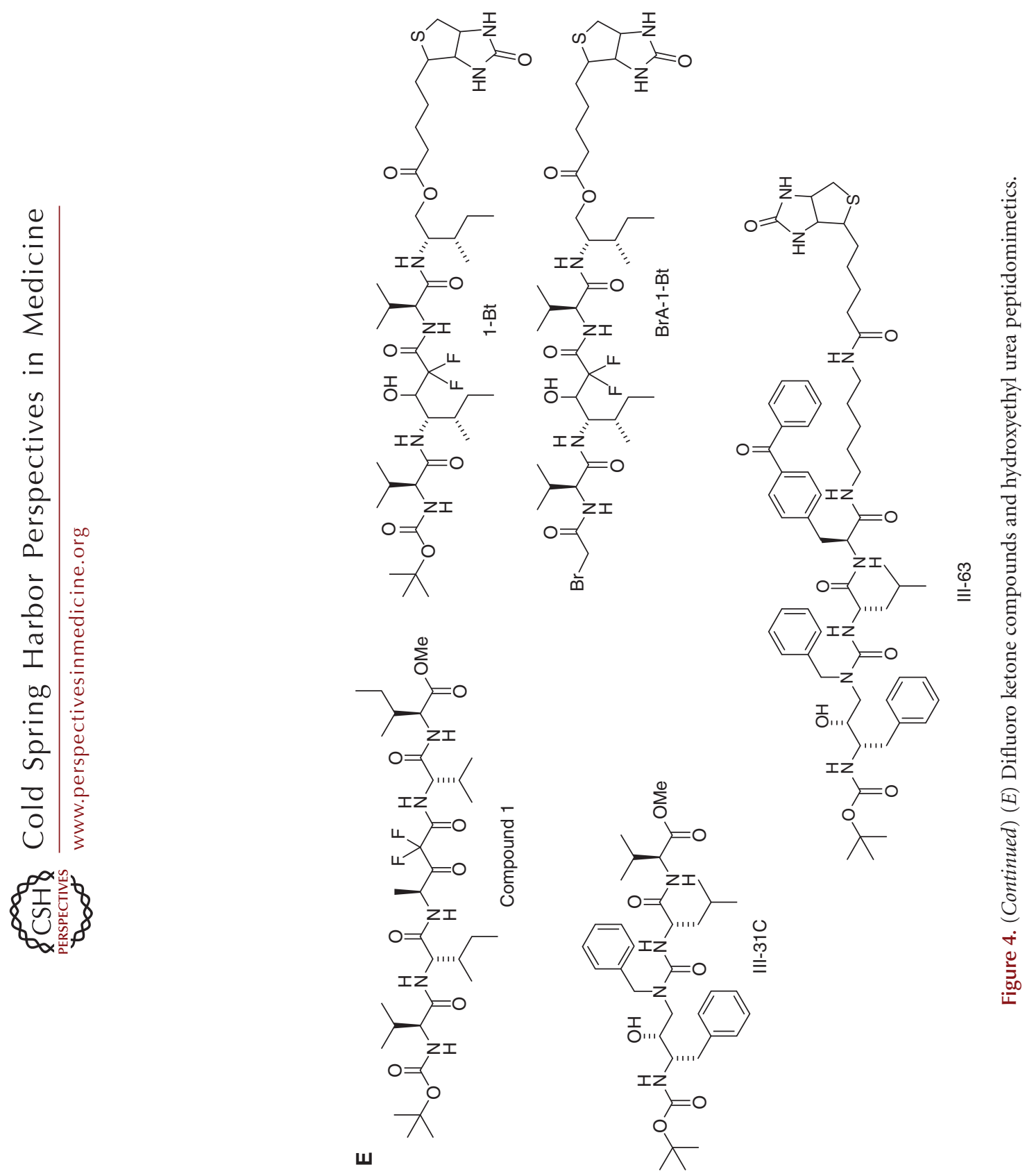
F

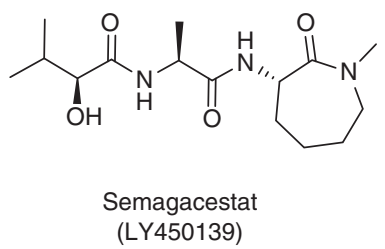

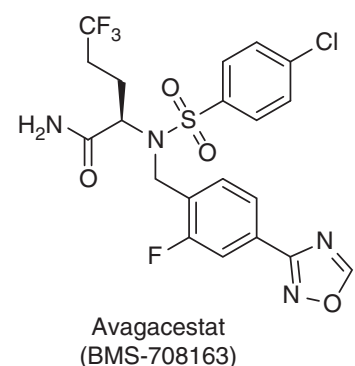

(BMS-708163)

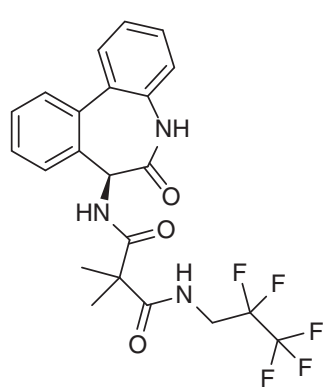

$\mathrm{RO} 4929097$

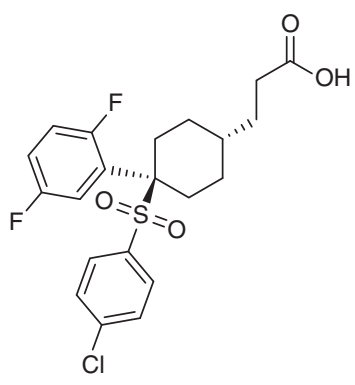

MK-0752

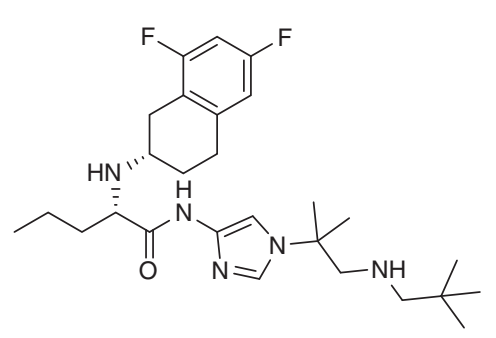

PF03084014

Figure 4. (Continued) $(F)$ Clinical $\gamma$-secretase inhibitors for Alzheimer's disease and cancer.

2001; Nicolas et al. 2003). The mechanism of cognitive decline, which remains unclear, has raised significant questions about the use of GSIs for AD treatment. Was the clinical trial suitably designed to avoid Notch-mediated toxicity (De Strooper 2014)? Does cognitive decline come from blockage of Notch cleavage or other $\gamma$-secretase substrates? Does the accumulation of APP $\beta$ CTF cause neurotoxicity (Mitani et al. 2012)? Low concentrations of GSIs can cause $A \beta$ elevation, and withdrawing GSIs leads to a rebound of $A \beta$ production in the plasma. Do these facts underlie the neurotoxicity (Lanz et al. 2006)? Together, these data suggest that total inhibition of APP processing could actually aggravate $\mathrm{AD}$ pathology and lead to worsening cognition. Finally, a fundamental question is whether loss or gain of function of PS1 mutations leads to AD (Shen and Kelleher 2007; Xia et al. 2015), which significantly impacts the development of $\gamma$-secretase-based and even $\mathrm{A} \beta$-based therapy for $\mathrm{AD}$ treatment.

Initially, avagacestat was reported as a "Notch-sparing" GSI (Gillman et al. 2010), which inhibits the processing of APP while leav- ing Notch signaling intact. However, the mechanism of avagacestat is controversial (ChávezGutiérrez et al. 2012; Crump et al. 2012b). In addition to gastrointestinal and dermatologic complications associated with Notch inhibition, higher doses also led to cognitive decline (Coric et al. 2012), indicating that avagacestat may share a common mechanism of toxicity with semagacestat.

A number of GSIs, including RO4929097, MK-0752, and PF-3084014, are being evaluated for the treatment of leukemia, lymphoma, and advanced solid cancer (https://clinicaltrials. gov $/$ ct $2 /$ results?term $=$ gamma-secretase + inhibitors + and + cancer\&Search $=$ Search) (Andersson and Lendahl 2014). Earlier clinical studies of MK-0752 were linked with dose-limiting gastrointestinal toxicity (DeAngelo et al. 2006), which is likely because of inhibition of Notch1 and Notch2 in intestinal crypts (van Es et al. 2005). Recently, two phase I studies assessed safety, maximum-tolerated dose (MTD), pharmacokinetics (PK), pharmacodynamics $(\mathrm{PD})$, and preliminary antitumor efficacy of MK-0752 and RO4929097 in patients 
D.S. Johnson et al.

with advanced solid tumors (Krop et al. 2012; Tolcher et al. 2012). Both GSIs were administrated in three different schedules. RO4929097 was well tolerated at $270 \mathrm{mg}$ on schedule A (3 days on, 4 days off during weeks 1 and 2, every 3 weeks; then 3 days on, 4 days off during subsequent cycles) and at $135 \mathrm{mg}$ on schedule B (7 consecutive days, every 3 weeks) (Tolcher et al. 2012). Moreover, a weak and moderate PK/PD correlation was observed for A $\beta 40$ or VEGFR-2 in plasma as well as Hes-1 mRNA expression in hair follicles (Tolcher et al. 2012). MK-0752 was generally well tolerated at $3200 \mathrm{mg}$ on schedule $\mathrm{C}$ (once per week) and resulted in strong modulation of a Notch gene signature (Krop et al. 2012). Moreover, clinical benefit was observed in both trials, which suggests that although GSIbased therapies have been unsuccessful to date for $\mathrm{AD}$, they may have a clearer indication in the treatment of Notch-sensitive malignancies (Gounder and Schwartz 2012).

\section{$\gamma$-Secretase Modulators (GSMs)}

Because of the safety concerns with inhibition of $\gamma$-secretase, alternative approaches to modulate $\gamma$-secretase activity have attracted much attention. The notion of $\gamma$-secretase modulation was introduced in 2001 when it was discovered that a subset of nonsteroidal anti-inflammatory drugs (NSAIDs), such as ibuprofen, indomethacin, and sulindac sulfide, selectively lowered A $\beta 42$ levels but increased $A \beta 38$ production without inhibiting Notch1 cleavage (Weggen et al. 2001).

GSMs have a unique profile compared with GSIs. They (1) cause selective decrease of A $\beta 42$ or decrease of both $A \beta 42$ and $A \beta 40$; (2) cause an increase in shorter $A \beta$ species $(A \beta 38$ and/or $\mathrm{A} \beta 37$ ); (3) cause no significant effect on the total amount of $A \beta$ produced; (4) cause no accumulation of APP- $\beta$ CTF; (5) preserve $\varepsilon$ cleavage of $\gamma$-secretase substrates, thus sparing APP- and Notch-ICD production; and (6) cause no plasma $A \beta$ rebound (Crump et al. 2013). Not surprisingly, these desirable features garnered the attention of many pharmaceutical companies and have inspired the discovery of additional classes of GSMs as potential dis- ease-modifying agents for the treatment of $\mathrm{AD}$ (Pettersson et al. 2011, 2013). These GSMs can be generally divided into three categories: NSAID-derived carboxylic acid GSMs, nonNSAID heterocyclic GSMs, and natural product-derived GSMs (Fig. 5A-C) (Wagner et al. 2012; Crump et al. 2013). Overall, the acid GSMs reduce the production of $A \beta 42$ and promote the generation of $A \beta 38$ and have little effect on $A \beta 40$ production, total $A \beta$ levels, APP intracellular domain (AICD), and Notch1 processing (see below). The heterocyclic GSMs have a slightly different profile in that they lower the production of $A \beta 42$ and $A \beta 40$ while increasing the levels of $A \beta 38$ and $A \beta 37$ to differing degrees (see also below). The natural product-derived triterpene GSMs were discovered from the extract of the black cohosh plant and possess a distinct $A \beta$ profile, with a reduction in $A \beta 42$ and $A \beta 38$ and an increase in $A \beta 39$ and $\mathrm{A} \beta 37$. Although the implication of elevating $\mathrm{A} \beta 37$ or $\mathrm{A} \beta 38$ in $\mathrm{AD}$ is unknown, it is believed that the shorter forms are less prone to aggregation and less pathogenic than $\mathrm{A} \beta 42$, and there is some evidence that suggests these shorter species could actually inhibit the aggregation of A 342 . The molecular basis for how GSMs spare the $\varepsilon$ cleavage of APP and other substrates while decreasing the production of $A \beta 42$ is not known. Studies using photoaffinity probes have shown that the different classes of GSMs bind to PS1-NTF and have distinct allosteric binding sites (Pozdnyakov et al. 2013; Takeo et al. 2014). The precise binding sites on PS1-NTF are not known, but it is likely that binding causes conformational changes in the active site of presenilin, which alters the $\gamma$-cleavage sites, resulting in the different $A \beta$ profiles depending on the GSM (Fig. 5A).

\section{NSAID-Derived Acid GSMs}

The first generation of NSAID GSMs includes sulindac sulfide, indomethacin, $(R)$-ibuprofen, and $(R)$-flurbiprofen (tarenflurbil) (Fig. 5B) (Weggen et al. 2001). The NSAID-derived GSMs selectively lower the formation of $A \beta 42$ with a concomitant increase in the generation of A $\beta 38$, albeit with weak potency. Importantly, 
Presenilin Structure and Medicinal Chemistry

A

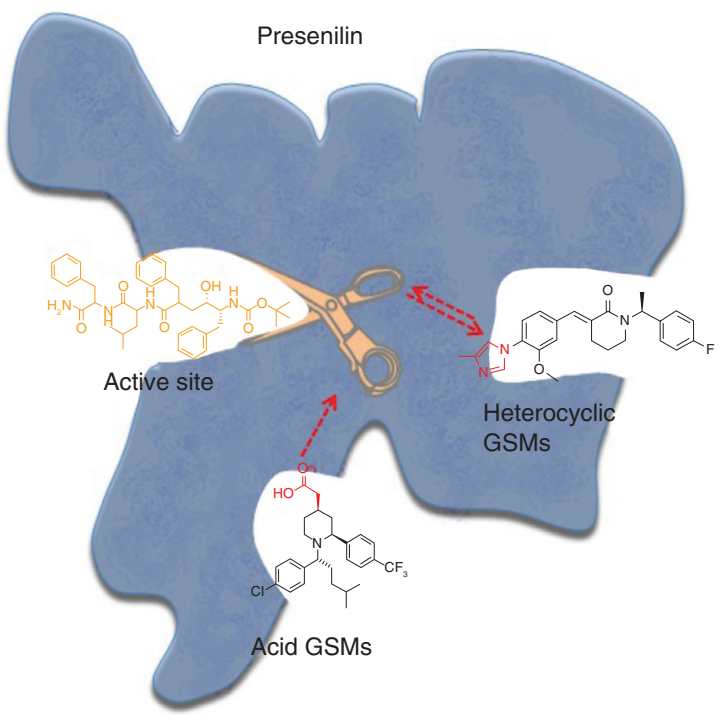

B<smiles>CC(C)Cc1ccc(C(C)C(=O)O)cc1</smiles>

(R)-Ibuprofen<smiles>CC(=O)c1ccc(-c2ccccc2)c(F)c1</smiles>

(R)-flurbiprofen (tarenflurbil)<smiles>O=C(O)C1(c2ccc(-c3ccc(Cl)c(Cl)c3)c(F)c2)CC1</smiles>

CHF5074<smiles>CC(C)CCC(c1ccc(Cl)cc1)N1CCC(CC(=O)O)CC1c1ccc(C(F)(F)F)cc1</smiles>

GSM-1<smiles>CC(C)CC[C@H](CCC(F)(F)F)N1CCC(CC(=O)O)CC1c1ccc(C(F)(F)F)cc1</smiles>

GSM-2<smiles>O=C(O)C(CC1CCC1)c1cc(Cl)c(OCC(F)(F)F)c(-c2ccc(C(F)(F)F)cc2)c1</smiles>

EVP-0015962<smiles>CC(C)CC(C(=O)O)c1cc(-c2ccc(C(F)(F)F)cc2)cc(-c2ccc(C(F)(F)F)cc2)c1</smiles>

JNJ-40418677<smiles>CC1CCN(C(c2ccc(F)cc2)c2ccc(C(C)C(=O)O)cc2-c2ccc(C(F)(F)F)cc2)CC1</smiles>

BIIB042

Figure 5. Allosteric $\gamma$-secretase modulators. (A) Cartoon showing allosteric interactions between the active site and the binding sites of heterocyclic and acid $\gamma$-secretase modulator compounds. (B) Structure of acid $\gamma$-secretase modulator compounds. (Continued on following page.)

these NSAIDs exhibited little to no effect on the proteolysis of other $\gamma$-secretase substrates such as Notch. $R$-flurbiprofen also selectively lowered $A \beta 42$ levels in a broken cell $\gamma$-secretase assay (Aß42 $\mathrm{IC}_{50} \sim 200-300 \mu \mathrm{M}$ ), suggesting a direct but weak interaction with $\gamma$-secretase (Eriksen et al. 2003). Despite its weak potency and poor brain penetration, tarenflurbil was advanced into clinical studies, but it did not slow cognitive decline in patients with mild $\mathrm{AD}$ in a phase 3 clinical trial. More recently, Chiesi developed a series of flurbiprofen analogs with improved potency for lowering $A \beta 42$, culminating in CHF5074 (A $342 \mathrm{IC}_{50}=3-$ 
D.S. Johnson et al.<smiles>COc1cc(/C=C2\CCCN3C2=NOC[C@H]3c2cc(F)c(F)c(F)c2)ccc1-n1cnc(C)c1</smiles><smiles>COc1nc(Nc2cccc3c2nc(-c2ccc(F)cc2)n3C)ccc1-n1cnc(C)c1</smiles><smiles>COc1cc(Nc2nc(Cc3ccc(Cl)cc3)cc(C(C)(C)O)n2)ccc1-n1cnc(C)c1</smiles><smiles>COc1cc(Nc2nc3c(c(COC4CCCC4)n2)COCC3)ccc1-n1cnc(C)c1</smiles><smiles>COc1cc(Nc2nc3n(n2)CCCC[C@H]3c2ccc(F)cc2)ccc1-n1cnc(Cl)c1</smiles><smiles></smiles><smiles>Cc1cn(-c2ccc3n(c2=O)CCN([C@@H](C)COc2ccc(F)cc2C(C)C(F)(F)F)C3=O)cn1</smiles>

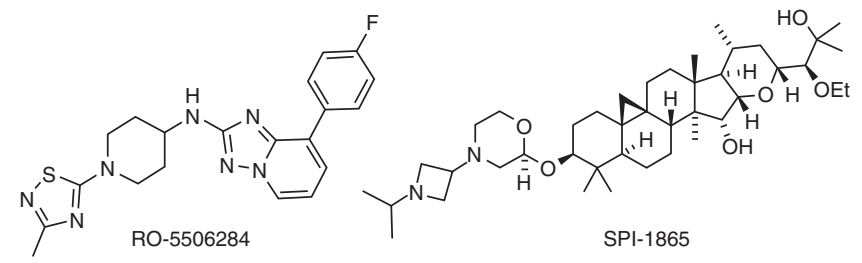

Figure 5. (Continued) (C) Structure of heterocyclic $\gamma$-secretase modulator compounds.

$41 \mu \mathrm{M})$ (Peretto et al. 2005). The pharmacokinetics and pharmacodynamics of CHF5074 $(200,400$, and $600 \mathrm{mg} / \mathrm{d})$ were evaluated in healthy subjects, and it was found that the soluble CD40 ligand, a marker of microglia activation, was lowered in a dose-dependent fashion (Imbimbo et al. 2013). However, no lowering of $A \beta$ levels in either plasma or cerebrospinal fluid (CSF) was detected, so the compound could act as a microglial modulator rather than as a GSM. Because of the weak potency and poor brain penetration, it has not been possible to test the GSM mechanism in the clinic with this class of compounds. Therefore, a key goal has been to develop GSM compounds with improved potency and brain availability. To that end, Merck has replaced the core aryl ring with a piperidine ring and optimized the substituents to generate a potent series of piperidine acetic acid GSMs, exemplified by GSM-1. GSM-1 has become the prototypical acid GSM with an $\mathrm{A} \beta 42 \mathrm{IC}_{50}$ value of $120-348 \mathrm{nM}$ (Fig. 5B) (Page et al. 2008, 2010). GSM-1 selectively reduced $A \beta 42$ and increased $A \beta 38$, whereas the levels of total 
$A \beta$ and AICD did not change. In addition, Astellas has reported the pharmacological profile of another piperidine acetic acid GSM referred to as GSM-2 (Mitani et al. 2012). GSM2 selectively lowered $A \beta 42\left(\mathrm{IC}_{50}=65 \mathrm{nM}\right)$, while increasing $\mathrm{A} \beta 38\left(\mathrm{EC}_{50}=81 \mathrm{nM}\right)$ with no effect on $\beta C T F$ levels or Notch signaling. In contrast to the GSIs LY450139 and BMS708,163 , when administered for 8 days, GSM-2 ameliorated the cognitive deficit in 5.5-monthold Tg2576 mice as measured in the Y-maze test. Although all three drugs reduced hippocampal $A \beta 42$ levels, $\beta C T F$ levels increased with the two GSIs but were unchanged with GSM-2. These data suggest that $\beta C T F$ elevation could partially explain the cognitive impairment associated with GSI treatment.

EnVivo, Janssen, and Biogen have returned to the phenylacetic acid core of flurbiprofen and added additional substituents on the core aryl ring-namely, the para-trifluoromethylphenyl that is present in GSM-1-to generate compounds with $\mathrm{A} \beta 42 \quad \mathrm{IC}_{50}$ values less than $200 \mathrm{nM}$ (Fig. 5B). EnVivo has introduced EVP0015962, which decreased $A \beta 42$ with an $\mathrm{IC}_{50}$ of $67 \mathrm{nM}$ while concomitantly increasing $A \beta 38$ (1.7-fold) (Rogers et al. 2012). Consistent with the profile of a GSM, A $\beta$ total, APP-CTFs, and AICD/NICD generation were not changed. Chronic treatment in Tg2576 mice with EVP$0015962(20$ and $60 \mathrm{mg} / \mathrm{kg} / \mathrm{d}$, which results in brain concentrations of 2.5 and $8.3 \mu \mathrm{M}$, respectively) reduced cytosolic, membrane-bound, and aggregated $\mathrm{A} \beta 42$; amyloid plaque load in the hippocampus; and cognitive deficits in the contextual fear-conditioning test. Janssen added a second trifluoromethylphenyl substituent to give JNJ-40418677, a brain-penetrant phenyl acetic acid GSM that reduced A $\beta 42$ secretion in cells and primary rat cortical neuronal cultures with an IC $_{50}$ of approximately $200 \mathrm{nM}$ (Van Broeck et al. 2011). JNJ-40418677 did not change levels of total $A \beta$, and Notch processing and AICD production were not affected. Acute treatment with JNJ-40418677 selectively reduced levels of $A \beta 42$ in the brains of wild-type mice with a concomitant increase in $A \beta 38$; however, chronic administration in Tg2576 mice from 6 to 13 months of age resulted in dose-dependent reductions of all $A \beta$ species in soluble and deposited fractions. In addition, a dose-dependent reduction in amyloid-plaque load was observed. The mechanism for the lowering of all $A \beta$ species in the soluble fraction with chronic treatment of this GSM is not known. Biogen incorporated additional features of GSM-1 onto the core of flurbiprofen to create BIIB042, which lowered $A \beta 42$ in $\mathrm{CHO}$ cells with an $\mathrm{IC}_{50}$ of $170 \mathrm{nM}$ and increased $\mathrm{A} \beta 38$ with an $\mathrm{EC}_{50}$ of $150 \mathrm{nM}$ (Peng et al. 2011). A reduction of brain $A \beta 42$ was observed when BIIB042 was administered to mice, rats, and cynomologus monkeys. In all of these examples, the gain in potency came at the expense of lipophilicity, and it remains to be seen whether an acceptable safety profile with adequate brain exposure at the target can be attained.

\section{Non-NSAID Heterocyclic GSMs}

The first non-NSAID-derived class of GSMs was initially reported by NeuroGenetics and further advanced by Eisai. It is characterized by an A-B-C-D-type heterocyclic framework, wherein a majority of the earlier series incorporates an arylimidazole moiety as the A-B subunit. Optimization of a $15 \mu \mathrm{M}$ high-throughput screening hit led to identification of the NeuroGenetics GSM NGP-555, which has an $\mathrm{A} \beta \mathrm{IC}_{50}$ of $10 \mathrm{nM}$ (Fig. 5C) (Kounnas et al. 2010). Unlike NSAID-derived acid GSMs, which selectively reduce $A \beta 42$, the non-NSAID-derived heterocyclic GSMs reduce both $A \beta 42$ and $A \beta 40$ while increasing the levels of $A \beta 38$ and $A \beta 37$. NGP-555 was evaluated in Tg2576 mice at doses of $5-100 \mathrm{mg} / \mathrm{kg}$ administered orally for 3 days, and an $\sim 30 \%$ reduction of brain $A \beta 42$ was observed at the $50 \mathrm{mg} / \mathrm{kg}$ dose. Efficacy was also demonstrated in a 7-month plaque-reduction study (Kounnas et al. 2010). Despite challenges with low solubility and high lipophilicity in this series, NGP-555 entered phase 1 clinical testing in 2015 (https://clinicaltrials.gov/ct2/results? term $=$ NGP-555\&Search $=$ Search, last accessed November 24, 2015).

A 2005 patent application from Eisai disclosed a related chemotype as exemplified by E2012 (Kimura et al. 2005). This compound 
D.S. Johnson et al.

incorporates a lactam as the central C-ring, and it became the prototypical heterocyclic GSM on which multiple organizations have initiated their own GSM programs. It has an A $\beta 42 \mathrm{IC}_{50}$ value of $92 \mathrm{nM}$ (Hashimoto et al. 2010), and robust in vivo activity was demonstrated in CSF biomarker studies in dogs and multiple rodent species (Portelius et al. 2010; Lu et al. 2012b). In 2006, E2012 became the first heterocyclic GSM to enter phase 1 clinical trials, and it was evaluated in a single ascending dose study with doses ranging from 1 to $400 \mathrm{mg}$, where an $\sim 50 \%$ reduction of plasma $A \beta 42$ was reported at the 400-mg dose (Nagy et al. 2010). The development of E2012 was subsequently halted because of lenticular opacity (cataract) in a 13-week rat safety study (Nakano-Ito et al. 2014). Although this safety finding was eventually de-risked, further development of E2012 was not pursued in favor of the more potent clinical candidate E2212 (A $\left.\beta 42 \mathrm{IC}_{50}=9 \mathrm{nM}\right)$, which was reported to have a better safety margin (Yu et al. 2014). In vivo profiling in guinea pig and rat indicate robust reductions of brain A 342 (Lu et al. 2012b). For example, a $15 \mathrm{mg} /$ $\mathrm{kg}$ oral dose in rat resulted in a $47.7 \%$ reduction of brain $A \beta 42$, whereas a dose of $100 \mathrm{mg} / \mathrm{kg}$ afforded an $\sim 70 \%$ reduction. E2212 was well tolerated in healthy human volunteers at doses up to and including $250 \mathrm{mg}$, and dose-dependent reduction of plasma $\mathrm{A} \beta 42$ was observed with a $53.6 \%$ reduction at the $250-\mathrm{mg}$ dose (Yu et al. 2014). The structure of E2212 has not been disclosed, but it is presumed to be as depicted in Fig. 5C.

Schering Plough (now Merck) has explored multiple scaffolds based on E2012, and this work resulted in the identification of oxadiazines as amide bioisosteres as exemplified by SP-53 (A $\left.342 \quad \mathrm{IC}_{50}=33 \mathrm{nM}\right)$ (Huang et al. 2012; Sun et al. 2012). When dosed orally at $3 \mathrm{mg} / \mathrm{kg}$ in rats, SP-53 achieved a $37 \%$ and $35 \%$ reduction of $\mathrm{A} \beta 42$ in the cortex and CSF, respectively. The GSMs NGP-555, E2012, E2212, and SP-53 contain an olefin as a rigid linker to connect the B- and C-rings. Several GSM programs throughout the industry have sought to replace the electron-rich olefin with an alternative linker, and the use of a secondary amine has become increasingly prevalent (Pettersson et al. 2013). This strategy was explored by researchers at Janssen, resulting in JNJ-42601572 (Aß42 $\left.\mathrm{IC}_{50}=16 \mathrm{nM}\right)$, which reduced brain $A \beta 42$ by $51 \%$ when dosed in mice at $10 \mathrm{mg} / \mathrm{kg}$ orally (Bischoff et al. 2012). As with a majority of GSMs described in the literature up to this point, JNJ-42601572 maintained high aromaticity and lipophilicty $(c \log P=5.3)$, and this may explain the signs of liver toxicity that were observed in dogs when dosed at $20 \mathrm{mg} / \mathrm{kg}$ orally.

The strategy of incorporating an NH-linker has been used by several other companies including Hoffman-La Roche, AstraZeneca, and BMS. A common theme has been to utilize an aminopyrimidine as the C-ring hydrogen bond acceptor, and in some cases, fuse it to a second aliphatic ring to impart additional conformational control. Hoffman-La Roche has disclosed GSMs such as RO-02, which has an A $342 \mathrm{IC}_{50}$ value of $15 \mathrm{nM}$ (Ebke et al. 2011). AstraZeneca has published structurally related GSMs including AZ4800, which has an $\mathrm{A} \beta 42 \mathrm{IC}_{50}$ of $26 \mathrm{nM}$ and lowered brain $A \beta 42$ by $46 \%$ when dosed orally at $130 \mathrm{mg} / \mathrm{kg}$ (Borgegard et al. 2012). BMS incorporated an aminotriazole core and a chloroimidazole A-ring in place of the commonly used 4-methylimidazole to afford potent GSMs such as BMS-869780 (Aß42 $\mathrm{IC}_{50}=$ $5.6 \mathrm{nM}$ ) (Toyn et al. 2014). PK/PD modeling indicated that a dose of $700 \mathrm{mg}$ would be required to achieve a $25 \%$ reduction of $A \beta 42$ in the human brain. The high projected human dose, taken together with observations of liver toxicity in rat, led to the discontinuation of BMS-869780 from further development.

In addition to connecting the $\mathrm{B}$ - and C-rings via an olefin or an $\mathrm{NH}$-linker, direct attachment has been explored by several companies (Pettersson et al. 2011). Following observations of liver toxicity with JNJ-42601572, Janssen used this approach to make significant improvements with regard to physicochemical properties as exemplified by GSM JNJ-16 (Gijsen and Mercken 2012; Oehlrich et al. 2013). This compound has an $\mathrm{A} \beta 42 \mathrm{IC}_{50}$ of $56 \mathrm{nM}$, but with significantly reduced lipophilicity relative to JNJ-42601572 ( $c \log P$ of 3.1 and 5.3 
for JNJ-16 and JNJ-42601572, respectively). JNJ-16 was evaluated in dogs with an oral dose of $20 \mathrm{mg} / \mathrm{kg}$, and a $30 \%-40 \%$ reduction in CSF A 342 was achieved. This level of efficacy was accompanied by high plasma exposure $(24 \mu \mathrm{M})$, but no signs of liver toxicity were observed. Furthermore, JNJ-16 was evaluated in a 2-wk rat safety study at a daily dose of $200 \mathrm{mg} /$ $\mathrm{kg}$ without observing overt liver toxicity. Although this is an encouraging advancement, the authors comment that the high exposures required to achieve robust $\mathrm{A} \beta$-lowering activity in vivo may not be compatible with long-term treatment. Thus, further improvements in efficacy will be needed to identify a viable clinical candidate.

Although the A-B section of the A-B-C-Dtype heteroaryl series has been highly conserved in the literature, a number of examples have emerged in which compounds differ significantly from earlier chemotypes. Pfizer has reported a novel series of GSMs incorporating a pyridopyrazine-1,6-dione heterocyclic core that allowed for improved alignment of potency, physicochemical properties, and ADME, ultimately leading to identification of PF$06442609\left(\mathrm{~A} \beta 42 \mathrm{IC}_{50}=6 \mathrm{nM}, c \log P=3.1\right)$ (Tran et al. 2013; Pettersson et al. 2014, 2015). This compound afforded a $41 \%$ reduction of brain $A \beta 42$ when dosed orally in guinea pig at $60 \mathrm{mg} / \mathrm{kg}$. An alternative series has also been reported by Roche, in which the aromatic B-ring has been replaced with a saturated piperidine as exemplified in RO5506284 (A $\beta 42 \mathrm{IC}_{50}=$ $25.7 \mathrm{nM}$ in H4-APP Swe cells) (Brendel et al. 2015). Brain A $\beta 42$ was reduced by $48 \%$ when dosed orally at $30 \mathrm{mg} / \mathrm{kg}$ in transgenic mice (APP-Swe). RO5506284 was also shown to inhibit de novo plaque formation upon dosing for 6 months, as assessed by amyloid PET imaging.

A novel class of natural-product-derived GSMs was identified by Satori. The initial lead, a triterpene glycoside, was isolated from the extract of the black cohosh plant and has an $\mathrm{A} \beta 42 \mathrm{IC}_{50}$ value of $100 \mathrm{nM}$ in H4 APP cells (Findeis et al. 2012). This new series has a unique $A \beta$ profile in which $A \beta 42$ and $A \beta 38$ are reduced and $A \beta 37$ and $A \beta 39$ are increased, whereas $A \beta 40$ remains relatively unchanged.
Optimization of the initial lead ultimately afforded the preclinical candidate SPI-1865 $\left(\mathrm{A} \beta 42 \mathrm{IC}_{50}\right.$ of $106 \mathrm{nM}$ ) (Hubbs et al. 2012, 2015; Loureiro et al. 2013). Following single oral doses of 10,30 , and $100 \mathrm{mg} / \mathrm{kg}$ in rat, SPI-1865 achieved brain A $\beta 42$ reduction of 21,37 , and $50 \%$, respectively, at the 24 -h time point following the final dose. However, further development of SPI-1865 was eventually halted because of adverse effects on adrenal function in monkeys (Hall and Patel 2014).

\section{CONCLUSIONS}

The recent structural studies on presenilin complexes, taken together with recent discoveries in the medicinal chemistry and chemical biology of the presenilin complexes that are reviewed here, represent a major advance toward understanding how the presenilin complexes work. The next steps for the field will be to build structural models of the complex associated with various inhibitors and modulators. By defining the consequent three-dimensional structural shifts in the architecture of the complex, it may eventually be possible to design compounds targeting specific substrates and/or specific cleavage products.

\section{ACKNOWLEDGMENTS}

This work is supported by grants-in-aid of research from the Canadian Institutes of Health Research, Wellcome Trust, Medical Research Council, National Institutes of Health Research, and the Alzheimer Society of Ontario.

\section{REFERENCES}

Ahn K, Shelton CC, Tian Y, Zhang X, Gilchrist ML, Sisodia SS, Li YM. 2010. Activation and intrinsic $\gamma$-secretase activity of presenilin 1. Proc Natl Acad Sci 107: 2143521440.

Andersson ER, Lendahl U. 2014. Therapeutic modulation of Notch signalling-Are we there yet? Nat Rev Drug Discov 13: $357-378$.

Bai XC, Rajendra E, Yang G, Shi Y, Scheres SH. 2015a. Sampling the conformational space of the catalytic subunit of human $\gamma$-secretase. eLife 4: e11182. 
D.S. Johnson et al.

Bai XC, Yan C, Yang G, Lu P, Ma D, Sun L, Zhou R, Scheres SH, Shi Y. 2015b. An atomic structure of human $\gamma$-secretase. Nature 525: 212-217.

Ballard TE, Murrey HE, Geoghegan KF, am Ende CW, Johnson DS. 2014. Investigating $\gamma$-secretase protein interactions in live cells using active site-directed clickable dual-photoaffinity probes. Med Chem Comm 5: 321327.

Beher D, Fricker M, Nadin A, Clarke EE, Wrigley JD, Li YM, Culvenor JG, Masters CL, Harrison T, Shearman MS 2003. In vitro characterization of the presenilin-dependent $\gamma$-secretase complex using a novel affinity ligand. Biochemistry 42: 8133-8142.

Bergman A, Laudon H, Winblad B, Lundkvist J, Naslund J. 2004. The extreme $C$ terminus of presenilin 1 is essential for $\gamma$-secretase complex assembly and activity. J Biol Chem 279: 45564-45572.

Bischoff F, Berthelot D, De CM, MacDonald G, Minne G, Oehlrich D, Pieters S, Surkyn M, Trabanco AA, Tresadern G, et al. 2012. Design and synthesis of a novel series of bicyclic heterocycles as potent $\gamma$-secretase modulators. J Med Chem 55: 9089-9106.

Borgegard T, Jureus A, Olsson F, Rosqvist S, Sabirsh A, Rotticci D, Paulsen K, Klintenberg R, Yan H, Waldman M, et al. 2012. First and second generation $\gamma$-secretase modulators (GSMs) modulate amyloid- $\beta$ (A $\beta$ ) peptide production through different mechanisms. J Biol Chem 287: 11810-11819.

Brendel M, Jaworska A, Herms J, Trambauer J, Rotzer C Gildehaus FJ, Carlsen J, Cumming P, Bylund J, Luebbers T, et al. 2015. Amyloid-PET predicts inhibition of de novo plaque formation upon chronic $\gamma$-secretase modulator treatment. Mol Psychiatry 20: 1179-1187.

Chau DM, Crump CJ, Villa JC, Scheinberg DA, Li YM. 2012. Familial Alzheimer disease presenilin-1 mutations alter the active site conformation of $\gamma$-secretase. J Biol Chem 287: 17288-17296.

Chávez-Gutiérrez L, Bammens L, Benilova I, Vandersteen A, Benurwar M, Borgers M, Lismont S, Zhou L, Van Cleynenbreugel S, Esselmann H, et al. 2012. The mechanism of $\gamma$-secretase dysfunction in familial Alzheimer disease. EMBO J 31: 2261-2274

Chen F, Hasegawa H, Schmitt-Ulms G, Kawarai T, Bohm C, Katayama T, Gu Y, Sanjo N, Glista M, Rogaeva E, et al. 2006. TMP21 is a presenilin complex component that modulates $\gamma$-secretase but not $\varepsilon$-secretase activity. Nature 440: $1208-1212$.

Chun J, Yin YI, Yang G, Tarassishin L, Li YM. 2004. Stereoselective synthesis of photoreactive peptidomimetic $\gamma$-secretase inhibitors. J Org Chem 69: 7344-7347.

Citron M, Westaway D, Xia W, Carlson G, Diehl T, Levesque G, Johnson-Wood K, Lee M, Seubert P, Davis A, et al. 1997. Mutant presenilins of Alzheimer's disease increase production of 42-residue amyloid $\beta$-protein in both transfected cells and transgenic mice. Nat Med 3: 67-72.

Coric V, van Dyck CH, Salloway S, Andreasen N, Brody M, Richter RW, Soininen H, Thein S, Shiovitz T, Pilcher G, et al. 2012. Safety and tolerability of the $\gamma$-secretase inhibitor avagacestat in a phase 2 study of mild to moderate Alzheimer disease. Arch Neurol 69: 1430-1440.

Crump CJ, Fish BA, Castro SV, Chau DM, Gertsik N, Ahn K, Stiff C, Pozdnyakov N, Bales KR, Johnson DS, et al. 2011.
Piperidine acetic acid based $\gamma$-secretase modulators directly bind to Presenilin-1. ACS Chem Neurosci 2: 705-710.

Crump CJ, am Ende CW, Ballard TE, Pozdnyakov N, Pettersson M, Chau DM, Bales KR, Li YM, Johnson DS. 2012a. Development of clickable active site-directed photoaffinity probes for $\gamma$-secretase. Bioorg Med Chem Lett 22: 2997-3000.

Crump CJ, Castro SV, Wang F, Pozdnyakov N, Ballard TE, Sisodia SS, Bales KR, Johnson DS, Li YM. 2012b. BMS708,163 targets presenilin and lacks notch-sparing activity. Biochemistry 51: 7209-7211.

Crump CJ, Johnson DS, Li YM. 2013. Development and mechanism of $\gamma$-secretase modulators for Alzheimer's disease. Biochemistry 52: 3197-3216.

DeAngelo DJ, Stone RM, Silverman LB, Stock W, Attar EC, Fearen I, Dallob A, Matthews C, Stone J, Freedman SJ, et al. 2006. A phase I clinical trial of the notch inhibitor MK-0752 in patients with T-cell acute lymphoblastic leukemia/lymphoma (T-ALL) and other leukemias. J Clin Oncol 24: 357S.

De Strooper B. 2014. Lessons from a failed $\gamma$-secretase Alzheimer trial. Cell 159: 721-726.

De Strooper B, Annaert W. 2010. Novel research horizons for presenilins and $\gamma$-secretases in cell biology and disease. Annu Rev Cell Dev Biol 26: 235-260.

De Strooper B, Annert W, Cupers P, Saftig P, Craessaerts K, Mumm JS, Schroeter EH, Schrijvers V, Wolfe MS, Ray WJ et al. 1999. A presenilin dependent $\gamma$-secretase-like protease mediates release of Notch intracellular domain. Nature 398: 518-522.

Doan A, Thinakaran G, Borchelt DR, Slunt HH, Ratovitsky T, Podlisny M, Selkoe DJ, Seeger M, Gandy SE, Price DL, et al. 1996. Protein topology of presenilin 1. Neuron 17: 1023-1030.

D’Onofrio G, Panza F, Frisardi V, Solfrizzi V, Imbimbo BP, Paroni G, Cascavilla L, Seripa D, Pilotto A. 2012. Advances in the identification of $\gamma$-secretase inhibitors for the treatment of Alzheimer's disease. Expert Opin Drug Discov 7: 19-37.

Doody RS, Raman R, Farlow M, Iwatsubo T, Vellas B, Joffe S, Kieburtz K, He F, Sun X, Thomas RG, et al. 2013. A phase 3 trial of semagacestat for treatment of Alzheimer's disease. N Engl J Med 369: 341-350.

Ebke A, Luebbers T, Fukumori A, Shirotani K, Haass C, Baumann K, Steiner H. 2011. Novel $\gamma$-secretase enzyme modulators directly target presenilin protein. J Biol Chem 286: 37181-37186.

Elad N, De Strooper B, Lismont S, Hagen W, Veugelen S, Arimon M, Horré K, Berezovska O, Sachse C, ChávezGutiérrez L. 2015. The dynamic conformational landscape of $\gamma$-secretase. J Cell Sci 128: 589-598.

Eriksen JL, Sagi SA, Smith TE, Weggen S, Das P, McLendon DC, Ozols VV, Jessing KW, Zavitz KH, Koo EH, et al. 2003. NSAIDs and enantiomers of flurbiprofen target $\gamma$-secretase and lower $\mathrm{A} \beta 42$ in vivo. J Clin Invest 112: 440-449.

Esler WP, Kimberly WT, Ostaszewski BL, Diehl TS, Moore CL, Tsai JY, Rahmati T, Xia W, Selkoe DJ, Wolfe MS. 2000. Transition-state analogue inhibitors of $\gamma$-secretase bind directly to presenilin-1. Nat Cell Biol 2: 428-434. 
Esler WP, Kimberly WT, Ostaszewski BL, Ye W, Diehl TS Selkoe DJ, Wolfe MS. 2002. Activity-dependent isolation of the presenilin $\gamma$-secretase complex reveals nicastrin and a $\gamma$ substrate. Proc Natl Acad Sci 99: 2720-2725.

Esler WP, Das C, Wolfe MS. 2004. Probing pockets S2-S4' of the $\gamma$-secretase active site with (hydroxyethyl) urea peptidomimetics. Bioorg Med Chem Lett 14: 1935-1938.

Fagan R, Swindells M, Overington J, Weir M. 2001. Nicastrin, a presenilin-interacting protein, contains an aminopeptidase/transferrin receptor superfamily domain. Trends Biochem Sci 26: 213-214.

Findeis MA, Schroeder F, McKee TD, Yager D, Fraering PC, Creaser SP, Austin WF, Clardy J, Wang R, Selkoe D, et al. 2012. Discovery of a novel pharmacological and structural class of $\gamma$ secretase modulators derived from the extract of Actaea racemosa. ACS Chem Neurosci 3 : 941-951.

Fluhrer R, Steiner H, Haass C. 2009. Intramembrane proteolysis by signal peptide peptidases: A comparative discussion of GXGD-type aspartyl proteases. J Biol Chem 284: 13975-13979.

Fortna RR, Crystal AS, Morais VA, Pijak DS, Lee VM, Doms RW. 2004. Membrane topology and nicastrin-enhanced endoproteolysis of APH-1, a component of the $\gamma$ secretase complex. J Biol Chem 279: 3685-3693.

Francis R, McGrath G, Zhang J, Ruddy DA, Sym M, Apfeld J, Nicoll M, Maxwell M, Hai B, Ellis MC, et al. 2002. aph-1 and pen-2 are required for Notch pathway signaling, $\gamma$-secretase cleavage of $\beta A P P$, and presenilin protein accumulation. Dev Cell 3: 85-97.

Friedmann E, Lemberg MK, Weihofen A, Dev KK, Dengler U, Rovelli G, Martoglio B. 2004. Consensus analysis of signal peptide peptidase and homologous human aspartic proteases reveals opposite topology of catalytic domains compared with presenilins. J Biol Chem 279: 50790-50798.

Gertsik N, Ballard TE, am Ende CW, Johnson DS, Li YM. 2014. Development of CBAP-BPyne, a probe for $\gamma$-secretase and presenilinase. Med Chem Comm 5: 338-341.

Gijsen HJ, Mercken M. 2012. $\gamma$-Secretase modulators: Can we combine potency with safety? Int J Alzheimer's Dis: 295207.

Gillman KW, Starrett JE, Parker MF, Xie K, Bronson JJ, Marcin LR, McElhone KE, Bergstrom CP, Mate RA, Williams R, et al. 2010. Discovery and evaluation of BMS-708163, a potent, selective and orally bioavailable $\gamma$-secretase inhibitor. ACS Med Chem Lett 1: 120-124.

Gounder MM, Schwartz GK. 2012. Moving forward one Notch at a time. J Clin Oncol 30: 2291-2293.

Gu Y, Chen F, Sanjo N, Kawarai T, Hasegawa H, Duthie M, Li W, Ruan X, Luthra A, Mount HT, et al. 2003. APH-1 interacts with mature and immature forms of presenilins and nicastrin and may play a role in maturation of presenilin'nicastrin complexes. J Biol Chem 278: 7374-7380.

Gu Y, Sanjo N, Chen F, Hasegawa H, Petit A, Ruan X, Li W, Shier C, Kawarai T, Schmitt-Ulms G, et al. 2004. The presenilin proteins are components of multiple membrane-bound complexes that have different biological activities. J Biol Chem 279: 31329-31336.

Hall A, Patel TR. 2014. $\gamma$-Secretase modulators: Current status and future directions. Prog Med Chem 53: 101145.
Hashimoto T, Ishibashi A, Hagiwara H, Murata Y, Takenaka O, Miyagawa T. 2010. E2012: A novel $\gamma$-secretase modulator-Pharmacology. Alzheimers Dement 6: S242.

Holmes O, Paturi S, Selkoe DJ, Wolfe MS. 2014. Pen-2 is essential for $\gamma$-secretase complex stability and trafficking but partially dispensable for endoproteolysis. Biochemistry 53: 4393-4406.

Huang X, Zhou W, Liu X, Li H, Sun G, Mandal M, Vicarel M, Zhu X, Bennett C, McCraken T, et al. 2012. Synthesis and SAR studies of fused oxadiazines as $\gamma$-secretase modulators for treatment of Alzheimer's disease. ACS Med Chem Lett 3: 931-935.

Hubbs JL, Fuller NO, Austin WF, Shen R, Creaser SP, McKee TD, Loureiro RM, Tate B, Xia W, Ives J, et al. 2012. Optimization of a natural product-based class of $\gamma$-secretase modulators. J Med Chem 55: 9270-9282.

Hubbs JL, Fuller NO, Austin WF, Shen R, Ma J, Gong Z, Li J, McKee TD, Loureiro RM, Tate B, et al. 2015. Minimization of drug-drug interaction risk and candidate selection in a natural product-based class of $\gamma$-secretase modulators. Bioorg Med Chem Lett 25: 1621-1626.

Imbimbo BP, Frigerio E, Breda M, Fiorentini F, Fernandez M, Sivilia S, Giardino L, Calza L, Norris D, Casula D, et al . 2013. Pharmacokinetics and pharmacodynamics of CHF5074 after short-term administration in healthy subjects. Alzheimer Dis Assoc Disord 27: 278-286.

Josien H. 2002. Recent advances in the development of $\gamma$-secretase inhibitors. Curr Opin Drug Discov Devel 5: 513-525.

Kim SH, Sisodia SS. 2005. A sequence within the first transmembrane domain of PEN-2 is critical for PEN-2-mediated endoproteolysis of presenilin 1. J Biol Chem 280 1992-2001.

Kimberly WT, LaVoie MJ, Ostaszewski BL, Ye W, Wolfe MS, Selkoe DJ. 2003. $\gamma$-Secretase is a membrane protein complex comprised of presenilin, nicastrin, Aph-1, and Pen2. Proc Natl Acad Sci 100: 6382-6387.

Kimura T, Kawano K, Doi E, Kitazawa N, Shin K, Miyagawa T, Kaneko T, Ito K, Takaishi M, Sasaki T, et al. 2005. Preparation of cinnamide, 3-benzylidenepiperidin-2one, phenylpropynamide compounds as amyloid $\beta$ production inhibitors. Eisai Co., Japan, pp. 679.

Kornilova AY, Das C, Wolfe MS. 2003. Differential effects of inhibitors on the $\gamma$-secretase complex. Mechanistic implications. J Biol Chem 278: 16470-16473.

Kornilova AY, Bihel F, Das C, Wolfe MS. 2005. The initial substrate-binding site of $\gamma$-secretase is located on presenilin near the active site. Proc Natl Acad Sci 102: 3230-3235.

Kounnas MZ, Danks AM, Cheng S, Tyree C, Ackerman E, Zhang X, Ahn K, Nguyen P, Comer D, Mao L, et al. 2010. Modulation of $\gamma$-secretase reduces $\beta$-amyloid deposition in a transgenic mouse model of Alzheimer's disease. Neuron 67: 769-780.

Krishnaswamy S. 2005. Exosite-driven substrate specificity and function in coagulation. J Thromb Haemost 3: 54-67.

Krop I, Demuth T, Guthrie T, Wen PY, Mason WP, Chinnaiyan P, Butowski N, Groves MD, Kesari S, Freedman SJ, et al. 2012. Phase I pharmacologic and pharmacodynamic study of the $\gamma$ secretase (Notch) inhibitor MK-0752 in adult patients with advanced solid tumors. J Clin Oncol 30: $2307-2313$. 
D.S. Johnson et al.

Lai MT, Chen E, Crouthamel MC, DiMuzio-Mower J, Xu M Huang Q, Price E, Register RB, Shi XP, Donoviel DB, et al. 2003. Presenilin-1 and presenilin-2 exhibit distinct yet overlapping $\gamma$-secretase activities. J Biol Chem 278: 22475-22481.

Lanz TA, Karmilowicz MJ, Wood KM, Pozdnyakov N, Du P, Piotrowski MA, Brown TM, Nolan CE, Richter KE, Finley JE, et al. 2006. Concentration-dependent modulation of amyloid- $\beta$ in vivo and in vitro using the $\gamma$-secretase inhibitor, LY-450139. J Pharmacol Exp Ther 319: 924-933.

Laudon H, Hansson EM, Melen K, Bergman A, Farmery MR, Winblad B, Lendahl U, von Heijne G, Naslund J. 2005. A nine-transmembrane domain topology for presenilin 1. J Biol Chem 280: 35352-35360.

Lazarov VK, Fraering PC, Ye W, Wolfe MS, Selkoe DJ, Li H. 2006. Electron microscopic structure of purified, active $\gamma$-secretase reveals an aqueous intramembrane chamber and two pores. Proc Natl Acad Sci 103: 6889-6894.

Lee SF, Shah S, Li H, Yu C, Han W, Yu G. 2002. Mammalian APH-1 interacts with presenilin and nicastrin and is required for intramembrane proteolysis of amyloid- $\beta$ precursor protein and Notch. J Biol Chem 277: 45013-45019.

Lee SF, Shah S, Yu C, Wigley WC, Li H, Lim M, Pedersen K, Han W, Thomas P, Lundkvist J, et al. 2004. A conserved GXXXG motif in APH-1 is critical for assembly and activity of the $\gamma$-secretase complex. J Biol Chem 279: 4144-4152.

Li YM, Lai MT, Xu M, Huang Q, DiMuzio-Mower J, Sardana MK, Shi XP, Yin KC, Shafer JA, Gardell SJ. 2000a. Presenilin 1 is linked with $\gamma$-secretase activity in the detergent solubilized state. Proc Natl Acad Sci 97: 6138-6143.

Li YM, Xu M, Lai MT, Huang Q, Castro JL, DiMuzio-Mower J, Harrison T, Lellis C, Nadin A, Neduvelil JG, et al. 2000b. Photoactivated $\gamma$-secretase inhibitors directed to the active site covalently label presenilin 1. Nature 405 : 689-694.

Li X, Dang S, Yan C, Gong X, Wang J, Shi Y. 2013. Structure of a presenilin family intramembrane aspartate protease. Nature 493: 56-61.

Li Y, Lu SH, Tsai CJ, Bohm C, Qamar S, Dodd RB, Meadows W, Jeon A, McLeod A, Chen F, et al. 2014. Structural interactions between inhibitor and substrate docking sites give insight into mechanisms of human PS1 complexes. Structure 22: 125-135.

Loureiro RM, Dumin JA, McKee TD, Austin WF, Fuller NO, Hubbs JL, Shen R, Jonker J, Ives J, Bronk BS, et al. 2013. Efficacy of SPI-1865, a novel $\gamma$-secretase modulator, in multiple rodent models. Alzheimers Res Ther 5: 19.

Lu SH, Jeon AH, Schmitt-Ulms G, Qamar S, Dodd R, McDonald B, Li Y, Meadows W, Cox K, Bohm C, et al. 2012a. Vigilin interacts with signal peptide peptidase. Proteome Sci 10: 33.

Lu Y, Riddell D, Hajos-Korcsok E, Bales K, Wood KM, Nolan CE, Robshaw AE, Zhang L, Leung L, Becker SL, et al. $2012 b$. Cerebrospinal fluid amyloid- $\beta(A \beta)$ as an effect biomarker for brain $A \beta$ lowering verified by quantitative preclinical analyses. J Pharmacol Exp Ther 342: 366-375.

Lu P, Bai XC, Ma D, Xie T, Yan C, Sun L, Yang G, Zhao Y, Zhou R, Scheres SH, et al. 2014. Three-dimensional structure of human $\gamma$-secretase. Nature 512: 166-170.

Mao G, Cui MZ, Li T, Jin Y, Xu X. 2012. Pen-2 is dispensable for endoproteolysis of presenilin 1, and nicastrin-Aph subcomplex is important for both $\gamma$-secretase assembly and substrate recruitment. J Neurochem 123: 837-844.

Martoglio B, Golde TE. 2003. Intramembrane-cleaving aspartic proteases and disease: Presenilins, signal peptide peptidase and their homologs. Hum Mol Genet 12: R201-R206.

Mitani Y, Yarimizu J, Saita K, Uchino H, Akashiba H, Shitaka Y, Ni K, Matsuoka N. 2012. Differential effects between $\gamma$-secretase inhibitors and modulators on cognitive function in amyloid precursor protein-transgenic and nontransgenic mice. J Neurosci 32: 2037-2050.

Nagy C, Schuck E, Ishibashi A, Nakatani Y, Rege B, Logovinsky V. 2010. E2012, a novel $\gamma$-secretase modulator, decreases plasma amyloid- $\beta$ (A $\beta$ ) levels in humans. Alzheimers Dement 6: S574.

Nakano-Ito K, Fujikawa Y, Hihara T, Shinjo H, Kotani S, Suganuma A, Aoki T, Tsukidate K. 2014. E2012-induced cataract and its predictive biomarkers. Toxicol Sci 137: 249-258.

Nicolas M, Wolfer A, Raj K, Kummer JA, Mill P, Van Noort M, Hui CC, Clevers H, Dotto GP, Radtke F. 2003. Notch1 functions as a tumor suppressor in mouse skin. Nat Genet 33: $416-421$.

Nishimura M, Yu G, Levesque G, Zhang DM, Ruel L, Chen F, Milman P, Holmes E, Liang Y, Kawarai T, et al. 1999. Presenilin mutations associated with Alzheimer disease cause defective intracellular trafficking of $\beta$-catenin, a component of the presenilin protein complex. Nat Med 5: $164-169$.

Oehlrich D, Rombouts FJ, Berthelot D, Bischoff FP, De Cleyn MA, Jaroskova L, Macdonald G, Mercken M, Surkyn M, Trabanco AA, et al. 2013. Design and synthesis of bicyclic heterocycles as potent $\gamma$-secretase modulators. Bioorg Med Chem Lett 23: 4794-4800.

Ogura T, Mio K, Hayashi I, Miyashita H, Fukuda R, Kopan R, Kodama T, Hamakubo T, Iwatsubo T, Tomita T, et al 2006. Three-dimensional structure of the $\gamma$-secretase complex. Biochem Biophys Res Commun 343: 525-534.

Osenkowski P, Li H, Ye W, Li D, Aeschbach L, Fraering PC, Wolfe MS, Selkoe DJ. 2009. Cryoelectron microscopy structure of purified $\gamma$-secretase at $12 \AA$ resolution. J Mol Biol 385: 642-652.

Overall CM. 2002. Molecular determinants of metalloproteinase substrate specificity: Matrix metalloproteinase substrate binding domains, modules, and exosites. Mol Biotechnol 22: 51-86.

Page RM, Baumann K, Tomioka M, Perez-Revuelta BI, Fukumori A, Jacobsen $\mathrm{H}$, Flohr A, Luebbers T, Ozmen $\mathrm{L}$, Steiner $\mathrm{H}$, et al. 2008. Generation of $A \beta_{38}$ and $A \beta_{42}$ is independently and differentially affected by familial Alzheimer disease-associated presenilin mutations and $\gamma$-secretase modulation. J Biol Chem 283: 677-683.

Page RM, Gutsmiedl A, Fukumori A, Winkler E, Haass C, Steiner H. 2010. $\beta$-amyloid precursor protein mutants respond to $\gamma$-secretase modulators. J Biol Chem 285: 17798-17810.

Pardossi-Piquard R, Yang SP, Kanemoto S, Gu Y, Chen F, Bohm C, Sevalle J, Li T, Wong PC, Checler F, et al. 2009. APH1 polar transmembrane residues regulate the assembly and activity of presenilin complexes. J Biol Chem 284: 16298-16307. 
Peng H, Talreja T, Xin Z, Cuervo JH, Kumaravel G, Humora MJ, Xu L, Rohde E, Gan L, Jung MY, et al. 2011. Discovery of BIIB042, a potent, selective, and orally bioavailable $\gamma$-secretase modulator. ACS Med Chem Lett 2: 786-791.

Peretto I, Radaelli S, Parini C, Zandi M, Raveglia LF, Dondio G, Fontanella L, Misiano P, Bigogno C, Rizzi A, et al. 2005. Synthesis and biological activity of flurbiprofen analogues as selective inhibitors of $\beta$-amyloid ${ }_{1-42}$ secretion. J Med Chem 48: 5705-5720.

Pettersson M, Kauffman GW, am Ende CW, Patel NC, Stiff C, Tran TP, Johnson DS. 2011. Novel $\boldsymbol{\gamma}$-secretase modulators: A review of patents from 2008 to 2010. Expert Opin Ther Pat 21: 205-226.

Pettersson M, Stepan AF, Kauffman GW, Johnson DS. 2013. Novel $\gamma$-secretase modulators for the treatment of Alzheimer's disease: A review focusing on patents from 2010 to 2012. Expert Opin Ther Pat 23: 1349-1366.

Pettersson M, Johnson DS, Subramanyam C, Bales KR, am Ende CW, Fish BA, Green ME, Kauffman GW, Mullins PB, Navaratnam T, et al. 2014. Design, synthesis, and pharmacological evaluation of a novel series of pyridopyrazine-1,6-dione $\gamma$-secretase modulators. J Med Chem 57: 1046-1062.

Pettersson M, Johnson DS, Humphrey JM, Butler TW, am Ende CW, Fish BA, Green ME, Kauffman GW, Mullins PB, O'Donnell CJ, et al. 2015. Design of pyridopyrazine1,6-dione $\gamma$-secretase modulators that align potency, MDR efflux ratio, and metabolic stability. ACS Med Chem Lett 6: 596-601.

Placanica L, Tarassishin L, Yang G, Peethumnongsin E, Kim SH, Zheng H, Sisodia SS, Li YM. 2009. Pen2 and presenilin-1 modulate the dynamic equilibrium of presenilin- 1 and presenilin-2 $\gamma$-secretase complexes. J Biol Chem 284: $2967-2977$.

Podlisny MB, Citron M, Amarante P, Sherrington R, Xia W, Zhang J, Diehl T, Levesque G, Fraser P, Haass C, et al. 1997. Presenilin proteins undergo heterogeneous endoproteolysis between $\mathrm{Thr}_{291}$ and $\mathrm{Ala}_{299}$ and occur as stable $\mathrm{N}$ - and C-terminal fragments in normal and Alzheimer brain tissue. Neurobiol Dis 3: 325-337.

Portelius E, Van Broeck B, Andreasson U, Gustavsson MK, Mercken M, Zetterberg H, Borghys H, Blennow K. 2010. Acute effect on the $A \beta$ isoform pattern in CSF in response to $\gamma$-secretase modulator and inhibitor treatment in dogs. J Alzheimers Dis 21: 1005-1012.

Pozdnyakov N, Murrey HE, Crump CJ, Pettersson M, Ballard TE, am Ende CW, Ahn K, Li YM, Bales KR, Johnson DS. 2013. $\gamma$-Secretase modulator (GSM) photoaffinity probes reveal distinct allosteric binding sites on presenilin. J Biol Chem 288: 9710-9720.

Prokop S, Shirotani K, Edbauer D, Haass C, Steiner H. 2004. Requirement of PEN-2 for stabilization of the presenilin $\mathrm{N}$-/C-terminal fragment heterodimer within the $\gamma$ secretase complex. J Biol Chem 279: 23255-23261.

Renzi F, Zhang X, Rice WJ, Torres-Arancivia C, GomezLlorente Y, Diaz R, Ahn K, Yu C, Li YM, Sisodia SS, et al. 2011. Structure of $\gamma$-secretase and its trimeric preactivation intermediate by single-particle electron microscopy. J Biol Chem 286: 21440-21449.

Rogaev EI, Sherrington R, Rogaeva EA, Levesque G, Ikeda M, Liang Y, Chi H, Lin C, Holman K, Tsuda T, et al. 1995. Familial Alzheimer's disease in kindreds with missense mutations in a gene on chromosome 1 related to the Alzheimer's disease type 3 gene. Nature 376: 775-778.

Rogers K, Felsenstein KM, Hrdlicka L, Tu Z, Albayya F, Lee W, Hopp S, Miller MJ, Spaulding D, Yang Z, et al. 2012. Modulation of $\gamma$-secretase by EVP-0015962 reduces amyloid deposition and behavioral deficits in $\mathrm{Tg} 2576$ mice. Mol Neurodegener 7: 61.

Sannerud R, Esselens C, Ejsmont P, Mattera R, Rochin L, Tharkeshwar AK, De Baets G, De Wever V, Habets R, Baert V, et al. 2016. Restricted location of PSEN2/ $\gamma$ secretase determines substrate specificity and generates an intracellular A $\beta$ pool. Cell 166: 193-208.

Scheuner D, Eckman C, Jensen M, Song X, Citron M, Suzuki N, Bird TD, Hardy J, Hutton M, Kukull W, et al. 1996. Secreted amyloid $\beta$-protein similar to that in the senile plaques of Alzheimer's disease is increased in vivo by the presenilin 1 and 2 and APP mutations linked to familial Alzheimer's disease. Nat Med 2: 864-870.

Serneels L, Dejaegere T, Craessaerts K, Horre K, Jorissen E, Tousseyn T, Hebert S, Coolen M, Martens G, Zwijsen A et al. 2005. Differential contribution of the three Aph1 genes to $\gamma$-secretase activity in vivo. Proc Natl Acad Sci 102: $1719-1724$.

Serneels L, Van Biervliet J, Craessaerts K, Dejaegere T, Horre K, Van Houtvin T, Esselmann H, Paul S, Schafer MK Berezovska O, et al. 2009. $\gamma$-Secretase heterogeneity in the Aph1 subunit: Relevance for Alzheimer's disease. Science 324: 639-642.

Shah S, Lee SF, Tabuchi K, Hao YH, Yu C, Laplant Q, Ball H, Dann CE III, Sudhof T, Yu G. 2005. Nicastrin functions as a $\gamma$-secretase-substrate receptor. Cell 122: 435-447.

Shearman MS, Beher D, Clarke EE, Lewis HD, Harrison T, Hunt P, Nadin A, Smith AL, Stevenson G, Castro JL. 2000. L-685,458, an aspartyl protease transition state mimic, is a potent inhibitor of amyloid $\beta$-protein precursor $\gamma$ secretase activity. Biochemistry 39: 8698-8704.

Shelton CC, Zhu L, Chau D, Yang L, Wang R, Djaballah H, Zheng H, Li YM. 2009. Modulation of $\gamma$-secretase specificity using small molecule allosteric inhibitors. Proc Natl Acad Sci 106: 20228-20233.

Shen J, Kelleher RJ III. 2007. The presenilin hypothesis of Alzheimer's disease: Evidence for a loss-of-function pathogenic mechanism. Proc Natl Acad Sci 104: 403-409.

Sherrington R, Rogaev EI, Liang Y, Rogaeva EA, Levesque G, Ikeda M, Chi H, Lin C, Li G, Holman K, et al. 1995. Cloning of a gene bearing missense mutations in earlyonset familial Alzheimer's disease. Nature 375: 754-760.

Shirotani K, Edbauer D, Capell A, Schmitz J, Steiner H, Haass C. 2003. $\gamma$-Secretase activity is associated with a conformational change of nicastrin. J Biol Chem 278: 16474-16477.

Siemers ER, Dean RA, Friedrich S, Ferguson-Sells L, Gonzales C, Farlow MR, May PC. 2007. Safety, tolerability, and effects on plasma and cerebrospinal fluid amyloid- $\beta$ after inhibition of $\boldsymbol{\gamma}$-secretase. Clin Neuropharmacol 30: 317-325.

Sobhanifar S, Schneider B, Lohr F, Gottstein D, Ikeya T, Mlynarczyk K, Pulawski W, Ghoshdastider U, Kolinski M, Filipek S, et al. 2010. Structural investigation of the C-terminal catalytic fragment of presenilin 1. Proc Natl Acad Sci 107: 9644-9649. 
D.S. Johnson et al.

Spasic D, Raemaekers T, Dillen K, Declerck I, Baert V, Serneels L, Fullekrug J, Annaert W. 2007. Rer1p competes with APH-1 for binding to nicastrin and regulates $\gamma$ secretase complex assembly in the early secretory pathway. J Cell Biol 176: 629-640.

Steiner H, Fluhrer R, Haass C. 2008. Intramembrane proteolysis by $\gamma$-secretase. J Biol Chem 283: 29627-29631.

Sun ZY, Asberom T, Bara T, Bennett C, Burnett D, Chu I, Clader J, Cohen-Williams M, Cole D, Czarniecki M, et al. 2012. Cyclic hydroxyamidines as amide isosteres: Discovery of oxadiazolines and oxadiazines as potent and highly efficacious $\gamma$-secretase modulators in vivo. J Med Chem 55: 489-502.

Takasugi N, Tomita T, Hayashi I, Tsuruoka M, Niimura M, Takahashi Y, Thinakaran G, Iwatsubo T. 2003. The role of presenilin cofactors in the $\gamma$-secretase complex. Nature 422: $438-441$.

Takeo K, Tanimura S, Shinoda T, Osawa S, Zahariev IK, Takegami N, Ishizuka-Katsura Y, Shinya N, TakagiNiidome S, Tominaga A, et al. 2014. Allosteric regulation of $\gamma$-secretase activity by a phenylimidazole-type $\gamma$ secretase modulator. Proc Natl Acad Sci 111: $10544-$ 10549.

Tarassishin L, Yin YI, Bassit B, Li YM. 2004. Processing of Notch and amyloid precursor protein by $\gamma$-secretase is spatially distinct. Proc Natl Acad Sci 101: 17050-17055.

Teranishi Y, Hur JY, Welander H, Franberg J, Aoki M, Winblad B, Frykman S, Tjernberg LO. 2010. Affinity pulldown of $\gamma$-secretase and associated proteins from human and rat brain. J Cell Mol Med 14: 2675-2686.

Thinakaran G, Borchelt DR, Lee MK, Slunt HH, Spitzer L, Kim G, Ratovitsky T, Davenport F, Nordstedt C, Seeger M, et al. 1996. Endoproteolysis of presenilin 1 and accumulation of processed derivatives in vivo. Neuron 17: $181-190$.

Tian G, Sobotka-Briner CD, Zysk J, Liu X, Birr C, Sylvester MA, Edwards PD, Scott CD, Greenberg BD. 2002. Linear non-competitive inhibition of solubilized human $\gamma$ secretase by pepstatin A methylester, L685458, sulfonamides, and benzodiazepines. J Biol Chem 277: 31499_ 31505.

Tian Y, Bassit B, Chau D, Li YM. 2010. An APP inhibitory domain containing the Flemish mutation residue modulates $\gamma$-secretase activity for $\mathrm{A} \beta$ production. Nat Struct Mol Biol 17: 151-158.

Tolcher AW, Messersmith WA, Mikulski SM, Papadopoulos KP, Kwak EL, Gibbon DG, Patnaik A, Falchook GS, Dasari A, Shapiro GI, et al. 2012. Phase I study of RO4929097, a $\gamma$ secretase inhibitor of Notch signaling in patients with refractory metastatic or locally advanced solid tumors. J Clin Oncol 30: 2348-2353.

Toyn JH, Thompson LA, Lentz KA, Meredith JE Jr, Burton CR, Sankaranararyanan S, Guss V, Hall T, Iben LG, Krause $\mathrm{CM}$, et al. 2014. Identification and preclinical pharmacology of the $\gamma$-secretase modulator BMS-869780. Int $J$ Alzheimers Dis 2014: 431858.

Tran TP, Mullins PB, am Ende CW, Pettersson M. 2013. Synthesis of pyridopyrazine-1,6-diones from 6-hydroxypicolinic acids via a one-pot coupling/cyclization reaction. Org Lett 15: 642-645.

Van Broeck B, Chen JM, Tréton G, Desmidt M, Hopf C, Ramsden N, Karran E, Mercken M, Rowley A. 2011.
Chronic treatment with a novel $\gamma$-secretase modulator, JNJ-40418677, inhibits amyloid plaque formation in a mouse model of Alzheimer's disease. Br J Pharmacol 163: 375-389.

van Es JH, van Gijn ME, Riccio O, van den Born M, Vooijs M, Begthel H, Cozijnsen M, Robine S, Winton DJ, Radtke F, et al. 2005. Notch $/ \gamma$-secretase inhibition turns proliferative cells in intestinal crypts and adenomas into goblet cells. Nature 435: 959-963.

Villa JC, Chiu D, Brandes AH, Escorcia FE, Villa CH, Maguire WF, Hu CJ, de Stanchina E, Simon MC, Sisodia SS, et al. 2014. Nontranscriptional role of Hif- $1 \alpha$ in activation of $\gamma$-secretase and notch signaling in breast cancer. Cell Rep 8: 1077-1092.

Wagner SL, Tanzi RE, Mobley WC, Galasko D. 2012. Potential use of $\gamma$-secretase modulators in the treatment of Alzheimer disease. Arch Neurol 69: 1255-1258.

Watanabe N, Tomita T, Sato C, Kitamura T, Morohashi Y, Iwatsubo T. 2005. Pen-2 is incorporated into the $\gamma$-secretase complex through binding to transmembrane domain 4 of presenilin 1. J Biol Chem 280: 41967-41975.

Watanabe N, Takagi S, Tominaga A, Tomita T, Iwatsubo T. 2010. Functional analysis of the transmembrane domains of presenilin 1: Participation of transmembrane domains 2 and 6 in the formation of initial substrate-binding site of $\gamma$-secretase. J Biol Chem 285: 19738-19746.

Weggen S, Eriksen JL, Das P, Sagi SA, Wang R, Pietrzik CU, Findlay KA, Smith TE, Murphy MP, Bulter T, et al. 2001. A subset of NSAIDs lower amyloidogenic $A \beta 42$ independently of cyclooxygenase activity. Nature 414: 212-216.

Weihofen A, Binns K, Lemberg MK, Ashman K, Martoglio B. 2002. Identification of signal peptide peptidase, a presenilin-type aspartic protease. Science 296: 2215-2218.

Wolfe MS. 2013. Toward the structure of presenilin $/ \gamma$ secretase and presenilin homologs. Biochim Biophys Acta 1828: 2886-2897.

Wolfe MS, Xia W, Moore CL, Leatherwood DD, Ostaszewski B, Rahmati T, Donkor IO, Selkoe DJ. 1999a. Peptidomimetic probes and molecular modeling suggest that Alzheimer's $\gamma$-secretase is an intramembrane-cleaving aspartyl protease. Biochemistry 38: 4720-4727.

Wolfe MS, Xia W, Ostaszewski BL, Diehl TS, Kimberly WT Selkoe DS. 1999b. Two transmembrane aspartates in presenilin 1 required for presenilin endoproteolysis and $\gamma$ secretase activity. Nature 398: 513-517.

Xia X, Qian S, Soriano S, Wu Y, Fletcher AM, Wang XJ, Koo $\mathrm{EH}, \mathrm{Wu} \mathrm{X}$, Zheng H. 2001. Loss of presenilin 1 is associated with enhanced $\beta$-catenin signaling and skin tumorigenesis. Proc Natl Acad Sci 98: 10863-10868.

Xia D, Watanabe H, Wu B, Lee SH, Li Y, Tsvetkov E, Bolshakov VY, Shen J, Kelleher RJ III. 2015. Presenilin-1 knockin mice reveal loss-of-function mechanism for familial Alzheimer's disease. Neuron 85: 967-981.

Xie T, Yan C, Zhou R, Zhao Y, Sun L, Yang G, Lu P, Ma D, Shi Y. 2014. Crystal structure of the $\gamma$-secretase component nicastrin. Proc Natl Acad Sci 111: 13349-13354.

Xu M, Lai MT, Huang Q, DiMuzio-Mower J, Castro JL, Harrison T, Nadin A, Neduvelil JG, Shearman MS, Shafer JA, et al. 2002. $\gamma$-Secretase: Characterization and implication for Alzheimer disease therapy. Neurobiol Aging 23: 1023-1030. 
Yang DS, Tandon A, Chen F, Yu G, Yu H, Arawaka S, Hasegawa $\mathrm{H}$, Duthie M, Schmidt SD, Ramabhadran TV, et al. 2002. Mature glycosylation and trafficking of nicastrin modulate its binding to presenilins. J Biol Chem 277: 28135-28142.

Yang G, Yin YI, Chun J, Shelton CC, Ouerfelli O, Li YM. 2009. Stereo-controlled synthesis of novel photoreactive $\gamma$-secretase inhibitors. Bioorg Med Chem Lett 19: 922 925.

Yin YI, Bassit B, Zhu L, Yang X, Wang C, Li YM. 2007. $\gamma$ Secretase substrate concentration modulates the $A \beta 42$ A 340 ratio: Implications for Alzheimer disease. J Biol Chem 282: 23639-23644.

Yu G, Nishimura M, Arawaka S, Levitan D, Zhang L, Tandon A, Song YQ, Rogaeva E, Chen F, Kawarai T, et al. 2000 Nicastrin modulates presenilin-mediated notch/glp-1 signal transduction and $\beta$ APP processing. Nature 407: $48-54$.
Presenilin Structure and Medicinal Chemistry

Yu Y, Logovinsky V, Schuck E, Kaplow J, Chang MK, Miyagawa T, Wong N, Ferry J. 2014. Safety, tolerability, pharmacokinetics, and pharmacodynamics of the novel $\gamma$-secretase modulator, E2212, in healthy human subjects. J Clin Pharmacol 54: 528-536.

Zhang YW, Luo WJ, Wang H, Lin P, Vetrivel KS, Liao F, Li F, Wong PC, Farquhar MG, Thinakaran G, et al. 2005. Nicastrin is critical for stability and trafficking but not association of other presenilin $/ \gamma$-secretase components. J Biol Chem 280: 17020-17026.

Zhang X, Yu CJ, Sisodia SS. 2015. The topology of pen-2, a $\gamma$-secretase subunit, revisited: Evidence for a reentrant loop and a single pass transmembrane domain. $\mathrm{Mol} \mathrm{Neu-}$ rodegener 10: 39 .

Zhao G, Liu Z, Ilagan MX, Kopan R. 2010. $\gamma$-Secretase composed of PS1/Pen2/Aph1a can cleave notch and amyloid precursor protein in the absence of nicastrin. J Neurosci 30: 1648-1656. 


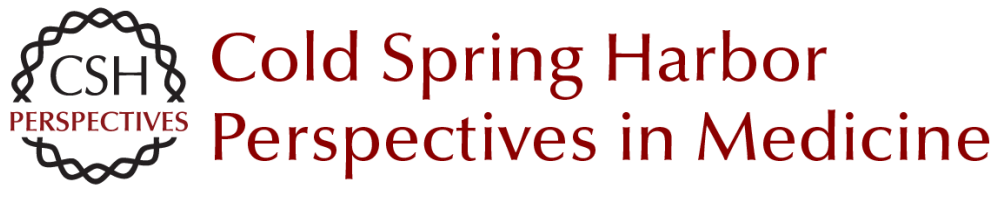

\section{Structural and Chemical Biology of Presenilin Complexes}

Douglas S. Johnson, Yue-Ming Li, Martin Pettersson and Peter H. St George-Hyslop

Cold Spring Harb Perspect Med 2017; doi: 10.1101/cshperspect.a024067 originally published online March 20, 2017

\section{Subject Collection Prion Diseases}

TDP-43 Prions

Takashi Nonaka and Masato Hasegawa

$\alpha$-Synuclein: Multiple System Atrophy Prions Amanda L. Woerman, Joel C. Watts, Atsushi Aoyagi, et al.

Genetics of Synucleinopathies Robert L. Nussbaum

$\beta$-Amyloid Prions and the Pathobiology of

Alzheimer's Disease Joel C. Watts and Stanley B. Prusiner

Disease Mechanisms of C9ORF72 Repeat Expansions

Tania F. Gendron and Leonard Petrucelli

Chronic Traumatic Encephalopathy: Is Latency in

Symptom Onset Explained by Tau Propagation? Joshua Kriegel, Zachary Papadopoulos and Ann C. McKee

Noncerebral Amyloidoses: Aspects on Seeding,

Cross-Seeding, and Transmission

Gunilla T. Westermark, Marcus Fändrich,

Katarzyna Lundmark, et al.

Structural and Chemical Biology of Presenilin

Complexes

Douglas S. Johnson, Yue-Ming Li, Martin

Pettersson, et al.
Cell Biology and Pathophysiology of $\alpha$-Synuclein Jacqueline Burré, Manu Sharma and Thomas C. Südhof

Molecular Mechanisms of Chronic Wasting

Disease Prion Propagation Julie A. Moreno and Glenn C. Telling

Genetics of Amyotrophic Lateral Sclerosis Mehdi Ghasemi and Robert H. Brown, Jr.

The Genetics of C9orf72 Expansions Ilse Gijselinck, Marc Cruts and Christine Van Broeckhoven

Prion-Like Characteristics of

Polyglutamine-Containing Proteins Margaret M.P. Pearce and Ron R. Kopito

Therapeutic Strategies for Restoring Tau Homeostasis

Zapporah T. Young, Sue Ann Mok and Jason E. Gestwicki

Fused in Sarcoma Neuropathology in Neurodegenerative Disease Ian R.A. Mackenzie and Manuela Neumann

Experimental Models of Inherited PrP Prion Diseases Joel C. Watts and Stanley B. Prusiner

For additional articles in this collection, see http://perspectivesinmedicine.cshlp.org/cgi/collection/ 